\title{
The Royal Commission on the Ancient and Historical Monuments of Scotland, Angus Graham and Gordon Childe (1935-46)
}

\author{
George F Geddes ${ }^{1}$
}

\begin{abstract}
This paper explores the story of Scotland's national survey body, the Royal Commission on the Ancient and Historical Monuments of Scotland, between 1935 and 1946, with reference to Angus Graham, their Secretary, and Vere Gordon Childe, perhaps the best-known archaeologist of the 20th century. Much of the narrative describes the Commission's survey of Orkney and Shetland, an eight year project which brought close contact with Childe, and special attention is given to debate over the Neolithic sites at Skara Brae and Rinyo. The outbreak of war in 1939 delayed their report for some seven years, but the government supported a major programme of rescue recording to mitigate damage caused by enemy bombing and the training of allied troops.

In 1938 Childe was passed over for membership of the Commission, who felt that they had sufficient archaeological expertise. His extreme anger at this snub was to be reflected in a negative review of their forthcoming report, but was allayed by neat footwork on the part of the chairman. In 1942, when the Commissioners did indeed put Childe forward as a member it was the Secretary of State for Scotland that stood in their way. Dedicated efforts by the Commission finally persuaded him that Childe was not in fact a Communist threat, and he and Graham went on to record some 636 ancient monuments, while Graham alone took 2,200 images of historic buildings. The archive material (and Graham's diaries in particular) shine a light on what was a pioneering project in testing times. The circumstances of the war, and the short duration of Childe's membership, meant that his influence was in fact felt through fieldwork and not, as one may have expected, in the development of the Commission's over-arching syntheses.
\end{abstract}

\section{INTRODUCTION}

Scotland's Royal Commission was the first of three established in Britain, and had the broad remit to:

\footnotetext{
Make an Inventory of the Ancient and Historical Monuments and Constructions connected with or illustrative of the contemporary culture, civilisation and conditions of life of the people in Scotland from the earliest times to 1707 , and to specify those which seem most worthy of preservation (RCAHMS 1909: v).
}

Details of the origins of the Commission are on record elsewhere, often through the sort of reminiscence that a small antiquarian project can produce (Graham 1981; Bell 1981; Dunbar 1992; Geddes 2013; RCAHMS 2015). In summary, a group of experts and figureheads were brought together in February 1908, and the initial forays into Scotland by their Secretary Alexander Curle were well received; a précis by Robert Munro provides an insight into contemporary attitudes (Munro 1915). The structure and administration of the Commission was derived from central government and overseen by the civil service. It was hierarchical: a Chairman led a group of Commissioners, who delegated the bulk of the work to a Secretary and, by the period under study here, three staff

${ }^{1}$ Heritage Directorate, Historic Environment Scotland, John Sinclair House, 16 Bernard Terrace, Edinburgh EH8 9NX 
(see Table 1). Meeting only a few times a year, neither the Chairman nor the Commissioners received remuneration, but their influence and expertise were central to the production of the reports and to the standards of fieldwork. The methodology that underpinned the reports was set out in their early meetings - a phase of research and correspondence was followed by a relatively comprehensive programme of fieldwork (eg RCAHMS 1909: v-vi). The publications provided an introductory synthesis, a list of monuments worthy of protection and

TABLE 1

Commissioners and staff $(1935-46)^{*}$

\begin{tabular}{|c|c|}
\hline Sir George Macdonald (d 1940) & Chairman \\
\hline Sir John Maxwell Stirling Maxwell & Commissioner; Chairman (appointed 1940) \\
\hline Dr Alexander Ormiston Curle & Commissioner \\
\hline Dr John Graham Callander (d 1938) & Commissioner \\
\hline James Archibald Morris (d 1942) & Commissioner \\
\hline Dr James Curle (d 1944) & Commissioner \\
\hline Prof Thomas Hastie Bryce (d 1946) & Commissioner \\
\hline Sir Iain Colquhoun & Commissioner (resigned 1942) \\
\hline Dr Reginald Francis Joseph Fairlie & Commissioner (appointed 1938) \\
\hline Prof Vere Gordon Childe & Commissioner (appointed 1942; resigned 1946) \\
\hline Prof Vivian Hunter Galbraith & Commissioner (appointed 1943) \\
\hline Dr William Mackay Mackenzie & Commissioner (appointed 1943) \\
\hline Dr Ian Archibald Richmond & Commissioner (appointed 1944) \\
\hline Prof Stuart Piggott & Commissioner (appointed 1946) \\
\hline Dr William Douglas Simpson & Commissioner (appointed 1946) \\
\hline \multicolumn{2}{|l|}{ Staff } \\
\hline Angus Graham & Secretary (appointed 1935) \\
\hline George Patrick Houston Watson & Architect \\
\hline Charles Shaw Tyrie Calder $\ddagger$ & Assistant architect and draughtsman \\
\hline John Maitland Corrie (d 1938) & Archaeologist \\
\hline Dr Kenneth Steer $\ddagger$ & Assistant archaeologist (appointed 1938) \\
\hline
\end{tabular}

* The titles, job descriptions and dates apply only to the period of study and are sourced from the Commission's minutes and reports.

† Absent on military service: Calder 1939-45, Steer 1939-46. 
a gazetteer of descriptions, all bound in an illustrated volume. A need for consistent and reliable information put fieldwork at the heart of the Commission's programme. By 1945 the staff and Commissioners had recorded over 8,000 sites. ${ }^{1}$

During the late 1930s, five pre-eminent scholars provided the Commission's archaeological expertise, most of whom had retired from a career in the civil service or academe. The Chairman, Sir George Macdonald (1862-1940), was a numismatist, Romanist and president of this Society among others (Curle 1940; Proc Soc Antiq Scot 75: 3). Of his Commissioners, James Curle (1862-1944) was particularly wellknown for his excavations at Roman Newstead (Curle 1911; Ritchie 2002); his younger brother, Alexander Curle (1866-1955), was the only person in Scotland to have successively held the posts of Secretary to the Commission,

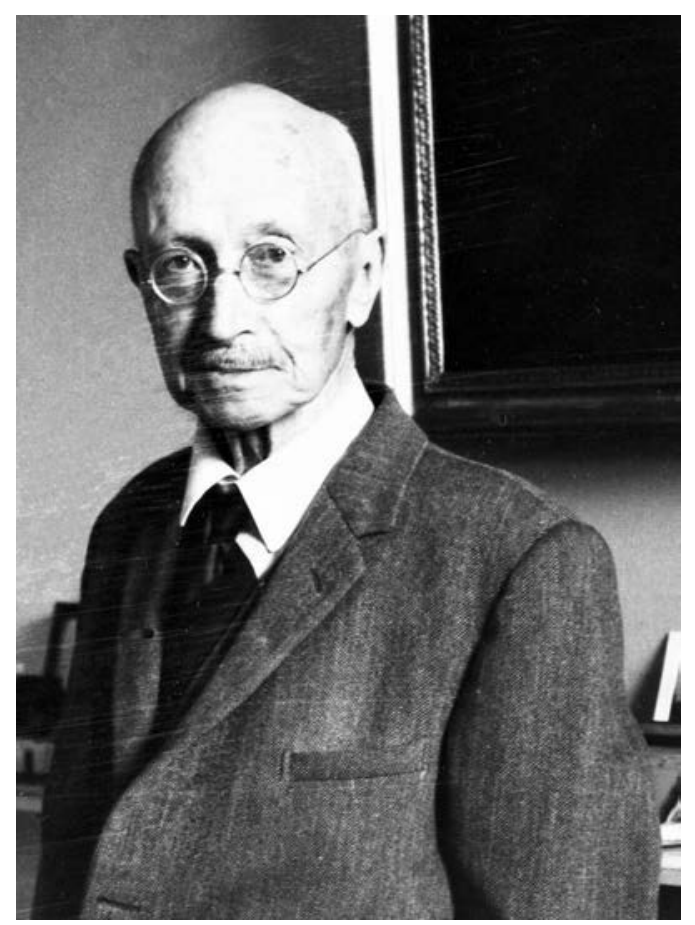

ILLus 1 Angus Graham at home, 1957. SC 1128482 (C) Crown Copyright: Historic Environment Scotland
Director of the National Museum of Antiquities of Scotland, and Director of the Royal Museum of Scotland (Richmond 1944; Graham 1956: 234-6; Ritchie 2002); Professor Thomas Bryce (1862-1946) of the University of Glasgow was an anatomist and excavator of chambered cairns (Arthur 1948; Forsyth et al 2006); and John Graham Callander (1873-1938) was, after A O Curle, Director of the National Museum of Antiquities of Scotland and held a unique 'knowledge of Scottish material' (Proc Soc Antiq Scot 72: 233). Remarkably, this quintet, who ranged between 62 and 73 years of age, had read more than 150 papers to this Society by $1935 .^{2}$

Angus Graham (1892-1979; Illus 1) had replaced William Mackay Mackenzie to become the Commission's third Secretary in 1935. Born at Skipness in Kintyre, Graham was educated at Winchester College and New College, Oxford, where he read Literae Humaniores. His interest in archaeology began early, prompted by that of his father, and focused on their estate (Graham 1915; 1919; 1920; Graham \& Collingwood 1923). Circumstances took him to France, Gallipoli and Palestine where he collected 'a bullet in the spine as well as a severe bout of dysentery from which his health never fully recovered' (Dunbar 1981: 1). After many years as a forester in Canada, he returned to Britain in 1933 (Gordon 1990; 1993), publishing his first novel The Golden Grindstone in 1935, which tackled gold prospecting in the Yukon territory. In April of that year, Graham learned from both A O Curle, and his friend the philosopher and archaeologist Robin G Collingwood, about the role of Secretary to the Royal Commission. He was one of 26 applicants, three of which were interviewed by a selection board consisting of Macdonald, A O Curle, Bryce and Professor Alexander Gray of the University of Edinburgh (representing the Civil Service Commission). ${ }^{3}$ Details of deliberation over the other interviewees are now lost, but Graham's previous record in archaeology, forestry and writing, not to mention his education, must have stood him in good stead. He was formally notified of his success on 2 July (writing 14 letters to celebrate) (RCAHMS 1946, v1: xv) and Sir George took 
the leading role during his introductory day a month later: ${ }^{4}$

1 August 1935. Went to office of Ancient Monuments Commission and assumed duty. Was introduced to staff by Sir G Macdonald; long conversations with Watson (am and at lunch) and Corrie and Callander (pm). Very tired and not well. Dined with Sir G Macdonald. ${ }^{5}$

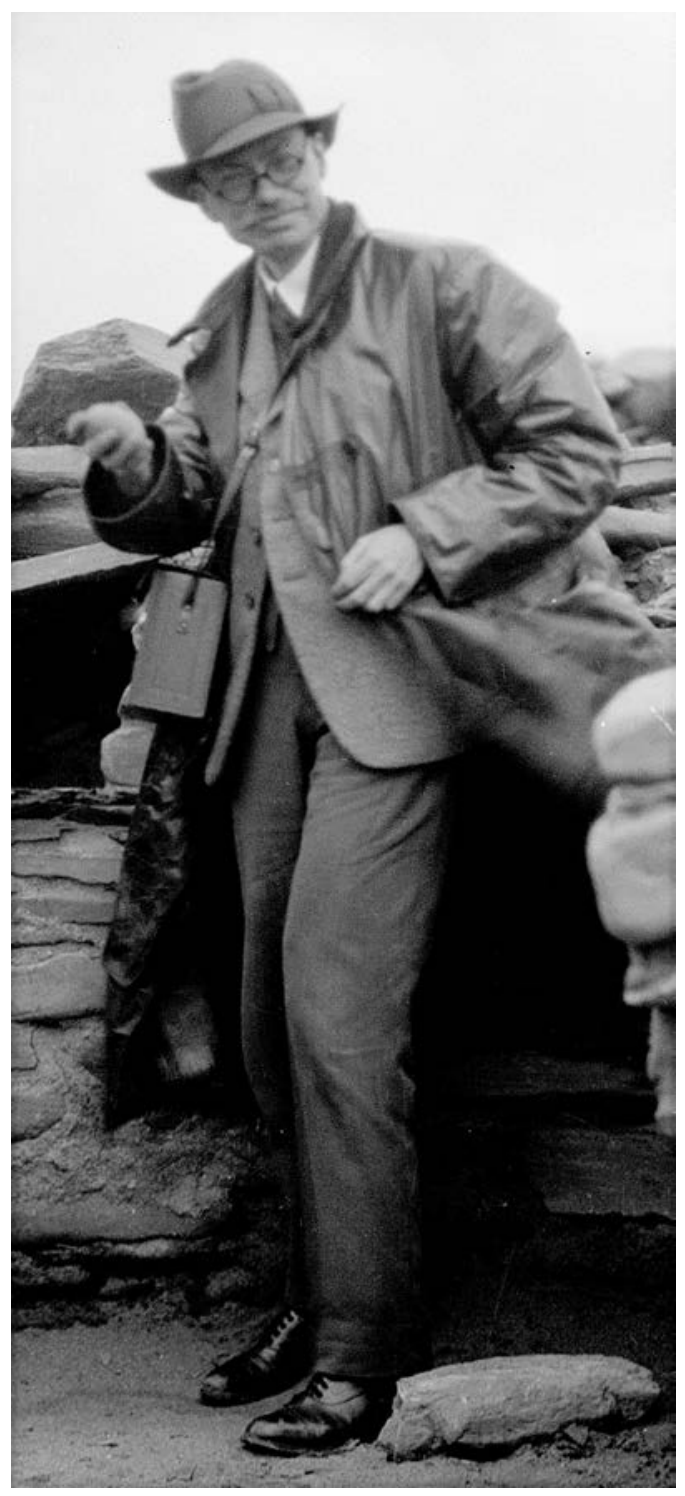

ILlus 2 Gordon Childe at Skara Brae, 1930. SC 372285 (C) courtesy of Historic Environment Scotland (Vere Gordon Childe Collection)
With RCAHMS and Graham, the third focus in this story is Vere Gordon Childe (1892-1957; Illus 2). Childe is perhaps the best-known archaeologist of the 20th century, with an importance to Scottish archaeology that far outweighs the results of his well-known excavations (Braidwood 1958; Rouse 1958; Sherratt 1989; Harris 1994; European Journal of Archaeology 12 eg Ralston 2009). During his tenure at the University of Edinburgh, he was Scotland's leading archaeologist, teaching, excavating and participating fully in the operations of the Ministry of Works, the museums and this Society (Ralston 2009: 58, 63). His two syntheses The Prehistory of Scotland (1935) and Scotland Before the Scots (1946) provided the first substantive update to Joseph Anderson's studies of some 50 years earlier $(1881 ; 1883$; 1886).

While few of Childe's private papers survive (Trigger 1994: 10), the Commission's administrative archive is both unbroken and untapped; and it is further complemented by the private and career papers of staff, in particular those of Graham himself. Childe's legacy and impact are well known, but Graham (born in the same year) was a notable player in Scottish archaeology, if not European. As well as steering the Commission for some 22 years and undertaking a great deal of fieldwork himself, he published regularly as a Fellow of this Society, and acted as its joint-secretary from 1937 to 1966 (Dunbar 1981). At times warm and engaging, his diaries shed light on the life of a researcher and an administrator that wrestled equally with the difficulties of running a small Government agency, and the examination of more or less glamorous elements of Scotland's past, whether Roman roads, harbours, cairnfields or tombstones (Illus 3).

During the 1930s, Sir George Macdonald and the Curle brothers dominated the Scottish archaeological establishment through their roles within the Commission, the museums and this Society (Graham 1956: 235-6; 1981: 212; Stevenson 1981). However, Graham later recalled the existence of an underground opposition fomented by Callander and supported by James Richardson (1883-1970), the first Inspector of 


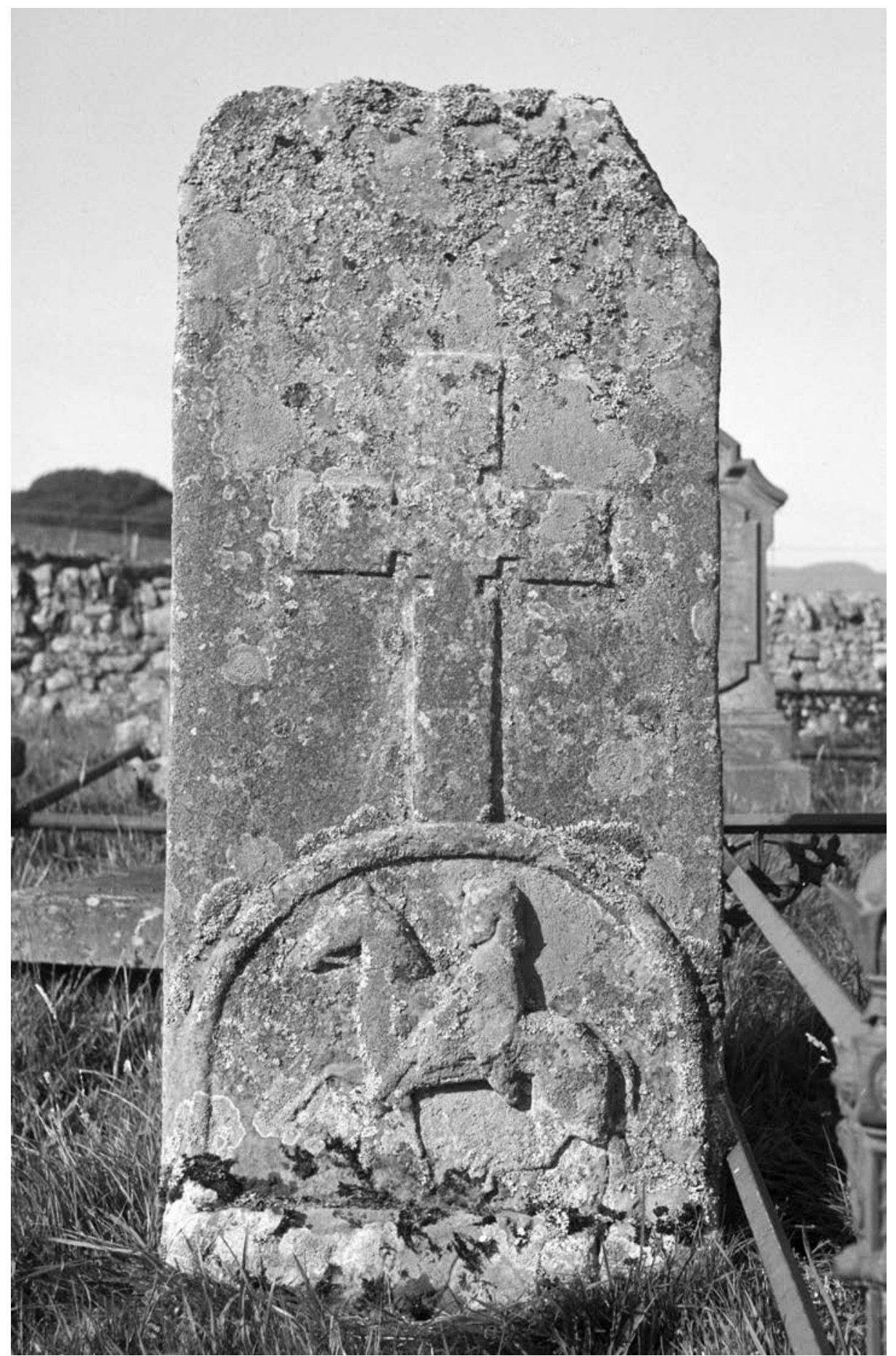

ILlus 3 Edderton, Ross and Cromarty, 1943. This fine medieval stone was captured during a day out recording prehistoric monuments in the area. SC 1401740 ㄷ Crown Copyright: Historic Environment Scotland 
Ancient Monuments in Scotland (Graham 1981: 212), a man with trenchant views that 'he did not hesitate to express' (ARC 1970: ix). Equally passionate, Callander used his place within the Commission to influence the development of their reports and often visited Graham to complain about his fellow Commissioners or to report 'a scene' with the Chairman. ${ }^{6}$ James Richardson's influence, though less direct, was brought to bear through regular meetings with Graham, and with particular reference to the monuments that would be recommended for protection. ${ }^{7}$ Childe, initially at least, was treated as an outsider (Green 1981: 59).

\section{RCAHMS AND CHILDE IN ORKNEY}

The principal business of the Commission was the production of reports with a list of sites recommended for protection. Its 11th report describing Fife, Kinross and Clackmannanshire appeared in 1933 and an anonymous reviewer, commenting in relation to medieval architecture, noted that it filled 'a noticeable gap in the vast though painfully sentimental literature which appears every year on Scotland' (Anon 1934: 496). Fieldwork in Orkney and Shetland had been underway for seven years when Graham was appointed and one of his first tasks was to get up to speed with the field and research materials. After tackling histories of Shetland and Anderson's by then aged synthesis, he headed north after only three weeks in the post, for a two-week familiarisation trip:

20 August 1935. Arrived Lerwick about noon after splendid passage. Went to Queen's Hotel. Drove with P Moar in pm to West Burrafirth; saw broch, stone, and burnt mound there, returned by Tingwall Loch, Asta (burnt mound and double cist), and Scalloway Palace. Beautiful afternoon and very interesting. ${ }^{8}$

Graham's staff were led by G P H Watson (1887-1959), architect (RCAHMS 2015: 867), supported by C S T Calder (1891-1972), assistant architect and draughtsman (ibid: 1012), and J M Corrie (1882-1938), archaeologist. In addition to their work in the Northern Isles, this trio were pursuing fieldwork both in the City of Edinburgh and in Roxburghshire, but progress was significantly delayed after 1934 by Corrie's deteriorating health (Reynolds 1984). At times, archaeological fieldwork was taken up by Commissioners Bryce and Callander, or the two architects. $^{9}$

As well as taking some part in fieldwork and administration, Graham put the volumes through the press and drafted the introductory material. The latter covered geology, history, and topography as well as a descriptive piece on the main classes of monument and material culture or 'relics'. It also provided an opportunity to touch on monuments that fell outwith the Commission's scope at the time, particularly those post-dating 1707. In Orkney and Shetland, these included merchant's booths, dovecots, kilns and water mills. Old field-dykes too, many of which 'no doubt date from before 1707 ' were not investigated because of 'the very large amount of work that would have been entailed in their survey, and also of the unavoidable uncertainty in allotting them to historical periods' (RCAHMS 1946, v1: 57). Graham also drafted the list of monuments 'the Commissioners deem most worthy of protection', written specifically for the Ministry of Works. In the counties of Fife, Kinross and Clackmannan, Orkney and Shetland, and Roxburgh (RCAHMS $1933 ; 1946 ; 1956)$, this group amounted to between $10 \%$ and $20 \%$ of the total number of sites recorded - although the 1946 list for the Northern Isles was much reduced from the initial draft. ${ }^{10}$

Editing was a more significant challenge. Each of the 1,761 articles in Orkney and Shetland required thorough checking for accuracy, clarity and consistency. ${ }^{11}$ These varied greatly in their length to reflect the complexity of the field and documentary evidence. While the majority were drafted by staff with the relevant expertise, some were written by Commissioners, others still by the authority better placed to take on the task - often an excavator, such as Childe himself (RCAHMS 1946, v1: no. 683, appendix no. 4). The cathedral of St Magnus, Kirkwall, represented the most significant single challenge in terms of scope and detail, some 20,000 words being dedicated to the 
building and early tombstones (RCAHMS 1946, v1: xvi; v2: 113-41). But the measured survey of such a large building was beyond their reach, and they relied on the drawings created by architect George Mackie Watson (1860-1948) during the building's restoration. ${ }^{12}$ Then, as now, it was the multi-period settlements that were most difficult to summarise adequately; Jarlshof in Shetland, for example, was described under five separate lengthy articles illuminating the prehistoric settlement, the broch, the Viking houses, and the 17th-century tombstones and house (RCAHMS 1946, v3: 14-23, 28-33, 37-41).

By September 1935, Graham was deeply involved in editing and drafting an introduction to the volume in close collaboration with the Commissioners and other authorities. It was whilst this work was ongoing, and just after reading Childe's Prehistory of Scotland, that the two met at a dinner party organised by Charles G Darwin (1887-1962), Professor of Natural Philosophy (Green 1981: 60). ${ }^{13}$ Despite the small size of the Scottish archaeological establishment, further meetings were only occasional and rarely exclusive - at a lecture, at a dinner or at an event for shared friends (Graham 1981: 222-3). ${ }^{14}$ Childe no doubt had contact with other members of the Commission, if principally through their respective roles within this Society (eg Proc Soc Antiq Scot 70: 2), and his published and unpublished work formed the basis for some Inventory articles (RCAHMS 1946, v1: xv). In turn, he certainly used the work of the Commission to inform his excavations and distributions; and references to their work can be found dotted throughout his excavations reports and his first Scottish synthesis (Childe 1935). At times, his excavations had been undertaken at the suggestion of Commissioners: work at Earn's Heugh being prompted by A O Curle (Childe \& Forde 1932: 152), and that at Kilfinan inspired in part by Bryce (Childe 1932: 415).

As RCAHMS Secretary, Graham was to become much better acquainted with Childe in connection with their respective work on Orkney and in particular Skara Brae. Graham paid a first visit to Skara Brae during his familiarising trip to the Northern Isles:
30 August 1935 . Weather began badly but improved. Went out by Stenness and Brodgar, where I took photographs, and Stones of Via to Skara Brae. Looked carefully over village and had lunch in teahouse. In pm, visited prehistoric rock-workings on Vestra Fiold; saw a house with a peat fire and no chimney; and looked at Fan Knowe. Arranged trip to Rousay by air. ${ }^{15}$

While the good state of preservation of their antiquities had long since attracted excavation, Orkney and Shetland received renewed attention in the late 1920s and 1930s, both from local antiquaries, and from agencies such as RCAHMS and the Ministry of Works (Ritchie 1995: 10 12). Relatively rapid excavation methods yielded extraordinary results (eg Curle 1935; Childe 1942a; Richardson 1948; Hutchison et al 2015). It was not only necessary for the Inventory to summarise the published excavations, but also to include information on discoveries that were new (RCAHMS 1946, v1: xvi). However, such was the pace of exploration that findings made after 1 September 1936 (effectively the last season of their fieldwork but for a few 'loose ends') were not included unless they were of special interest (RCAHMS 1946, v1: 62).

Providing such a summary was undemanding when the excavations were undertaken by a Commissioner (eg Callander \& Grant 1934; Curle 1935; Bryce 1940), or by a member of staff (eg Corrie \& Low 1929; Corrie 1932; Calder 1937; 1939), but it became more difficult if the results were delayed, particularly complex or unclear; or if an interpretation by the excavator could not be readily substantiated. Childe's excavations at Skara Brae between 1927 and 1930 were certainly complex (Childe \& Paterson 1929; Childe 1930; 1931a) (Illus 4) and the provision of an adequate and accurate summary was far from straightforward. While Childe had eventually settled on a Neolithic date for the main occupation, having previously identified a 'Pictish Village' (1931b), everything pivoted on the comparative analysis of the finds and architecture. His main detractor was Callander, who swiftly wrote a detailed re-analysis favouring an Iron Age date (Callander 1929; 1931; Green 1981: 70; Stevenson 1981: 196). As a Commissioner, 
and their foremost expert in early prehistory, Callander was Graham's first port of call, and effectively one his employers. Not only did Graham have to satisfy Callander, but also A O Curle and Macdonald - who took a keen interest in his work, and certainly retained the final word.

26 September 1935 . Worked mainly on description of Skara Brae, after discussion with Dr Callander. Rain came on in evening.

15 October 1935. Finished Neolithic section and gave to $\mathrm{J}$ G Callander to read. Called on Cursiter at National Gallery and looked up J W M Loney. ${ }^{16}$

Callander passed away unexpectedly in March 1938, his death coinciding exactly with the discovery of a new Orcadian prehistoric settlement at Rinyo on Rousay, an island where he had worked in the early 1930s (Callander \& Grant 1934). Although 'cist-like structures' had been noted by Commission staff in 1936, the first indications of greater significance were uncovered by a workman during the winter of 1937-8 (Childe \& Grant 1939: 6; RCAHMS 1946: no. 609; Childe \& Grant 1949). News spread fast and the site was recognised as being of crucial importance even before the excavation undertaken by the landowner, Walter Grant (1886-1947), and Childe in June and July 1938 (Reynolds \& Ritchie 1985):

2 February 1938. Was informed about new 'Skara Brae' discovery in Rousay by A O Curle; had conversations with him and Chairman about sending C S T Calder up there. Edited some proofs. Doctor called.

11 March 1938. Received Leica. Worked on proofs and routine. Went to see V G Childe about excavation in Rousay. ${ }^{17}$

In his initial summary of Rinyo, Childe drew many parallels with Skara Brae in terms of

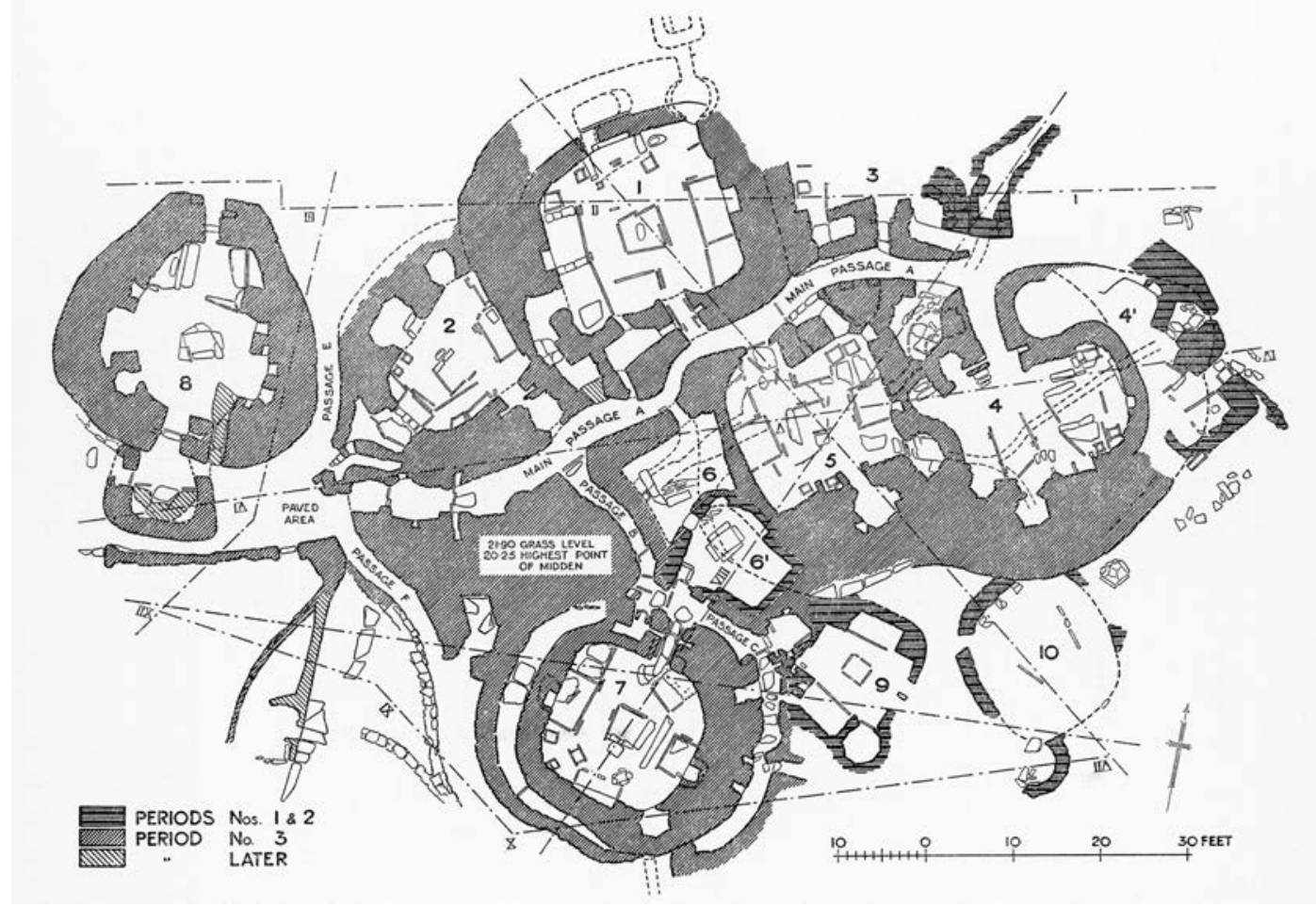

ILlus 4 The plan of Skara Brae was redrawn by Charles Calder for the Commission's County Inventory. SC 1470448 ( ) Crown Copyright: Historic Environment Scotland 
both architecture and material culture, but the 'exceptional importance of Rinyo' lay with the discovery of a fragment of all-over cord beaker in a secure context, suggesting that 'the village, and accordingly, Skara Brae too, were inhabited at a period when beakers were still fashionable in northern Scotland' (Childe 1938: 402; republished in RCAHMS 1946, v2: 364). Described by Ian Ralston as a 'confident summary' (2009: 56-7), the final Inventory description of Skara Brae was developed from notes originally provided by Childe, which were revised once again in 1938 in the light of these discoveries (RCAHMS 1946, v2: 254-9). ${ }^{18}$ Carefully written, it picks its way through the architectural evidence before summarising the finds assemblage, emphasising all the while the stratigraphic relationships and the multi-phase nature of occupation. Nuance was added to the question of date:

The lack of definite analogies with other sites led to much discussion regarding the period to which these remains should be attributed. However, in view of the discoveries made at the Braes of Rinyo since the foregoing account was written, the problem of the date of Skara Brae now seems to be in a fair way to solution (RCAHMS 1946, v2: 259).

Skara Brae and Rinyo were also mentioned in an introductory section entitled 'Early Domestic Remains' that allowed the reader to get a sense of how the pieces of the jigsaw might fit together (RCAHMS 1946, v1: 36-8):

Much the most important domestic site so far fully excavated in Orkney is that of Skara Brae; and its importance seems likely to be enhanced by the discoveries which, at the time of writing, are in progress at the Braes of Rinyo in Rousay, as these appear to be producing evidence for the dating of both sites not later than the Early Bronze Age (RCAHMS 1946, v1: 37).

The Commission was of course compelled to present the material in as objective a way as possible, while simultaneously reflecting the potential significance of the results. Such was the dynamic nature of Orcadian archaeology that it was perhaps impossible to create a description and synthesis that pleased everyone. As it was, relations between Childe and the Commission were strained by the end. This was not because of the Commission's reticence in accepting his interpretation of the date of Rinyo and Skara Brae, but was in fact because Childe felt that he should have been accepted onto the Commission after the death of Callander.

\section{CHILDE REJECTED}

Each Commissioner was appointed for life by a Royal Warrant issued by the King, on the advice of the Secretary of State for Scotland (eg RCAHMS 1946, v1: vii-xiii). Recommendations for appointments were sought by the Secretary of State through the Scottish Office, contacts within and outwith government, and from the Commission itself. In early 1938, the Commissioners recommended as their next member the esteemed Scottish architect Reginald Fairlie (1883-1952), a leading authority on medieval architecture (Nuttgens 1959; Graham 1981: 222) and a Royal Warrant was issued on 7 June that year after minimal deliberation by the Scottish Office (RCAHMS 1946, v1: xiii). ${ }^{19}$ This decision angered Gordon Childe, who wrote in objection to Graham, seeing himself as the natural candidate for Callander's replacement (this was to some extent tied up with their respective expertise on Scottish material culture). ${ }^{20}$ Since Childe's letter 'had been written under the influence of some violent emotion', Graham set it to one side but the matter was brought up again when Childe called in to see him two weeks later: 'we had a very amicable conversation - in fact he even volunteered a little more information about Rinyo - but I learned that he was furiously angry because he had not been offered a seat on the Commission'. ${ }^{21}$ Worse still, Childe explicitly threatened to write an unfavourable review of the unfinished Orkney and Shetland Inventory, as it seemed 'to appeal to him as a logical way of correcting the affront': 22

4 July 1938. Dangerous letter from Childe about Rinyo.

22 July 1938. Call from V G Childe in am; notified Chairman of his intention to write an unfavourable review of Inventory. Went to J M Corrie's funeral service. $^{23}$ 
Though deeply incensed, the Chairman, Sir George Macdonald, replied on behalf of the Commission in a 'soothingly courteous Whitehall tone', assuring Childe that he would have been hors concours (unrivalled) under normal circumstances, but pointed to the Commission's need of an expert architect, as future work would tackle both the fine medieval architecture of the Borders and the later buildings within Edinburgh (RCAHMS 1951: xvi; 1956; 1957; Graham 1981: 222-3). Macdonald ended on an uncharacteristically personal note describing his own marked disappointment and frustration on being passed over at the Commission's inception: 'as it was, I had to reconcile myself to spending fifteen years in the wilderness, content to give all the help I could from outside when my special period was touched upon'. ${ }^{24}$ It is now perhaps impossible to judge the degree to which Sir George was exaggerating the architectural angle, but it is certainly true that Edinburgh (RCAHMS 1951) was principally architectural in scope, while the prehistoric discoveries made possible by the use of aerial photographs and excavation in the Borders were perhaps unforeseeable in 1938 (RCAHMS 1956, v1: xxvi).

Whatever the truth, Childe backed down: 'Thank you very much for your exceedingly nice letter. I do see that prehistory is amply represented on the Commission in view of its immediate tasks', ${ }^{25}$ but relatively frosty relations may have continued until Macdonald's death in 1940, since he apparently regarded Childe in rather critical terms, not least because of his explicit leanings towards communism (Graham 1981: 223; Green 1981).

\section{WAR AND AN EMERGENCY ARCHITECTURAL SURVEY}

With the last hurdles of new discoveries and rewordings behind them, only the finalisation of the illustrations and proofs remained. The complete Orkney and Shetland Inventory was handed over to His Majesty's Stationery Office on 9 August 1939, although they did not publish the volume for a further seven years. ${ }^{26}$ Graham's diary recorded 'increasingly bad news' in following months with the threat of war looming and, in September, he began to pack away documents and organise emergency supplies. ${ }^{27}$ $\mathrm{He}$ also met with Childe (with whom he was again on good terms) to discuss how they might combine forces to help the German archaeologist and refugee Gerhard Bersu (Green 1981: 88; Díaz-Andreu 2009):

1 September 1939. At Dundee. Heard news that war had begun. Saw children being evacuated. Delivered paper to British Association on recent work of the Commission, meeting there J L Myres, Dr and Mrs Bersu, and Dr Bosch-Gimpera. Returned Edinburgh in $\mathrm{pm}$, in time to arrange for storage of valuables from office. Lighting restrictions. ${ }^{28}$

Discussion between the Lord Advocate, the Scottish Home Department (part of the Scottish Office from 1939), the Treasury and the Commission began on their immediate future, while two of the staff were swiftly mobilised: Calder with the Territorial Army and subsequently to a bomb-disposal unit in London, while Kenneth Steer, the new assistant archaeologist, was transferred to the Scottish Home Department and subsequently to the Monuments, Fine Arts and Archives programme. ${ }^{29}$ Allowance was also made for the call up of Graham and Watson, aged 47 and 52 respectively. Both were veterans of the Great War and had sustained permanently debilitating injuries, but Graham joined the Home Guard anyway.

In January 1940, the Treasury's Herbert Gatliff wrote to Graham about the wartime programme of the Commission: 'It is both the right course and the best answer to any criticism that might be made about spending money on such things in war time that they should, as far as possible, choose work that would be valuable in the event of important monuments being damaged during the war. ${ }^{30}$ In the discussions that followed, it was agreed that the initial focus would be on the photography of early buildings in Aberdeen, Glasgow, Kilmarnock and Paisley, all areas at risk of bombing that had yet to be covered by a County Inventory; work began immediately on gaining the necessary permissions and access. ${ }^{31}$ William Douglas Simpson, the librarian at the University of 
Aberdeen, provided Graham with a tour of the city in June 1940, just days before the first raid. ${ }^{32}$ The atmosphere in towns and cities was to make Graham's work initially almost impossible, with interference from the local population and police a significant difficulty (Illus 5): ${ }^{33}$

13 June $1940 \ldots$ went to Chief Constable's office to try to get permit, after being picked up by policeman for photographing. In pm went to Bridge of Don, but could not take photograph because of military guard. Hot day; not feeling at all well.

16 June $1940 \ldots$ was arrested while photographing Brig' of Balgownie in evening. Very unpleasant experience at hands of County Police. ${ }^{34}$

Due in part to these initial difficulties, photographic permissions were sought from each local constabulary, council, property owners, the military and the Ministry of Works. ${ }^{35}$ After returning to the main programme of work on the introductory material for the Edinburgh Inventory, it was not until October that Graham and Watson took up the task of recording Glasgow Cathedral, capturing some 80 photographs over a week:

7 October 1940. Spent whole day in Glasgow photographing cathedral. Two bombs during dinner, followed by short raid warning. Another, also short, about $10.15 \mathrm{pm}$. Got a cold. ${ }^{36}$

Typically, the subjects of Graham's photographic survey were high status ecclesiastical and secular buildings dating before 1707. As well as Glasgow, the cathedrals of Aberdeen ( $\mathrm{St}$ Machar's), Brechin, Dunblane, Dunkeld and Elgin were given extensive treatment, along with

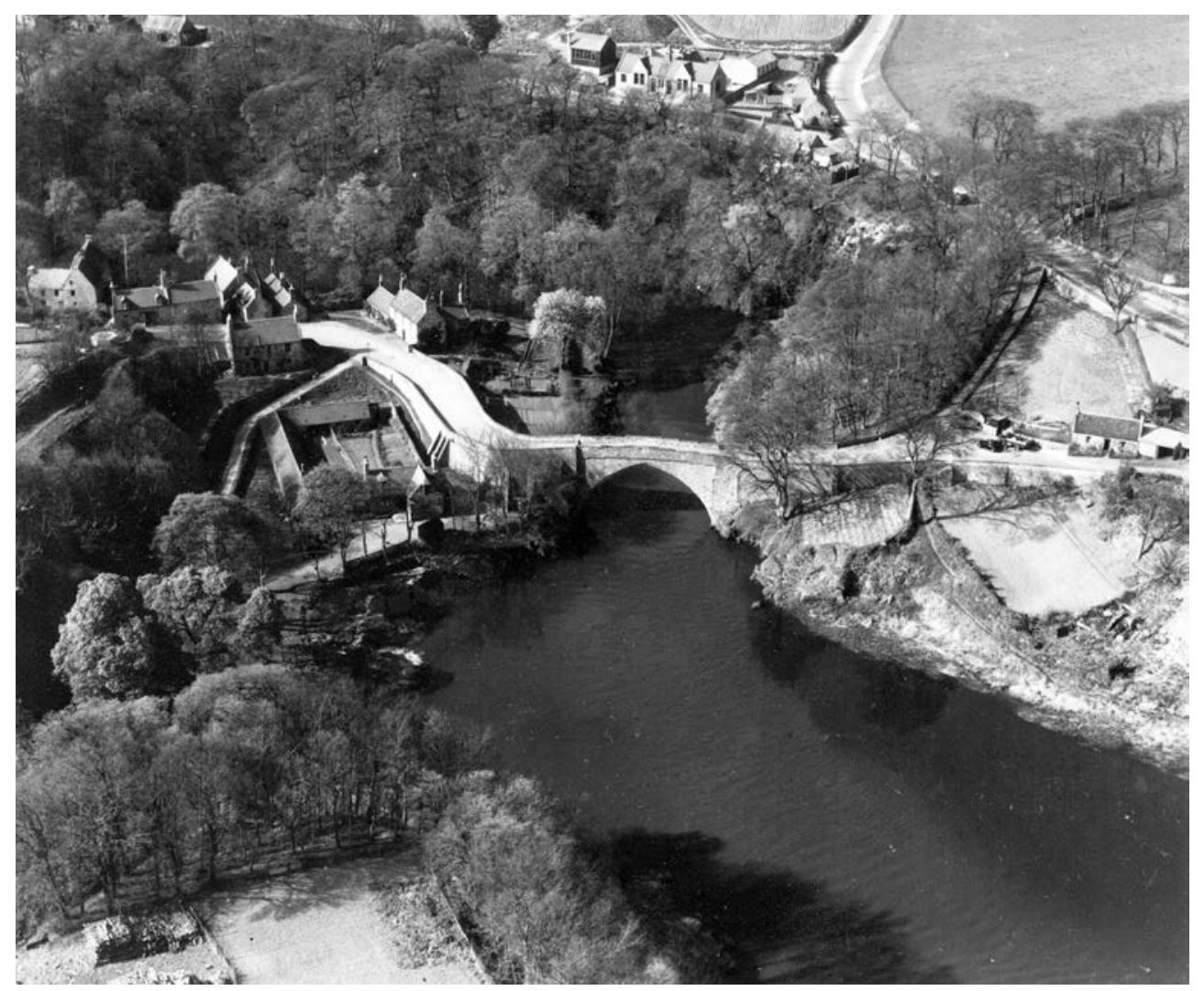

ILlus 5 Brig' of Balgownie, Aberdeen, 1948. It was here that Angus Graham was arrested in June 1940, suspected of being a spy. SC 1314736 C Historic Environment Scotland (Aerofilms Collection) 
some 40 churches and three abbeys. Over 90 medieval castles and towers provided the second major tranche, supplemented with about half as many houses of later date that still satisfied the terms of the Royal Warrant. Work continued on the survey of Edinburgh and Graham used the opportunity given by the Emergency Survey to gather additional imagery. By November 1941, he had collected some 1,300 photographs in areas with no County Inventory, all of buildings constructed before 1707 (Illus 6). ${ }^{37}$ Steps were taken to avoid duplication by contacting photographic studios (such as Valentines of
Dundee) or well-known photographers. ${ }^{38}$ Graham also corresponded with the Royal Incorporation of Architects in Scotland during the inception of the larger and much more ambitious Scottish National Buildings Record in 1941 (RCAHMS 2015: 45-7).

In a letter to England's Royal Commission, Graham described his equipment in some detail: 'I use a 5" $\times 4$ " Sanderson camera ... and for small details I use a Leica [Illus 7] ... As I am not an architect, I could not attempt any verbal description. ${ }^{39}$ Using methods that would today seem archaic, he treated most subjects to between

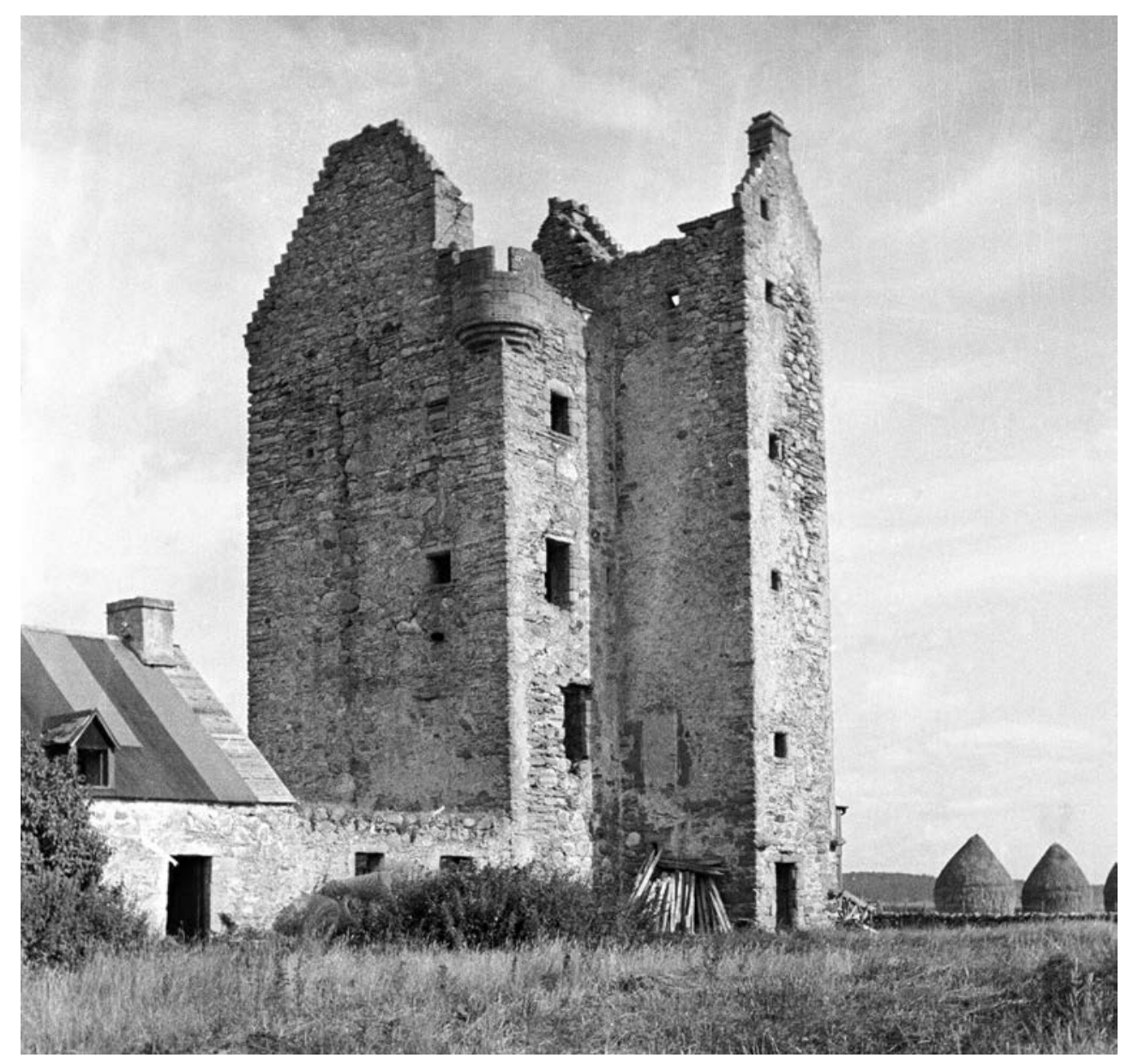

ILlus 6 Fairburn Tower, Ross and Cromarty, 1943. With a cut-off date of 1707, buildings such as this were at the upper limit of those recorded by RCAHMS in their early years. SC 1401657 (C) Crown Copyright: Historic Environment Scotland 


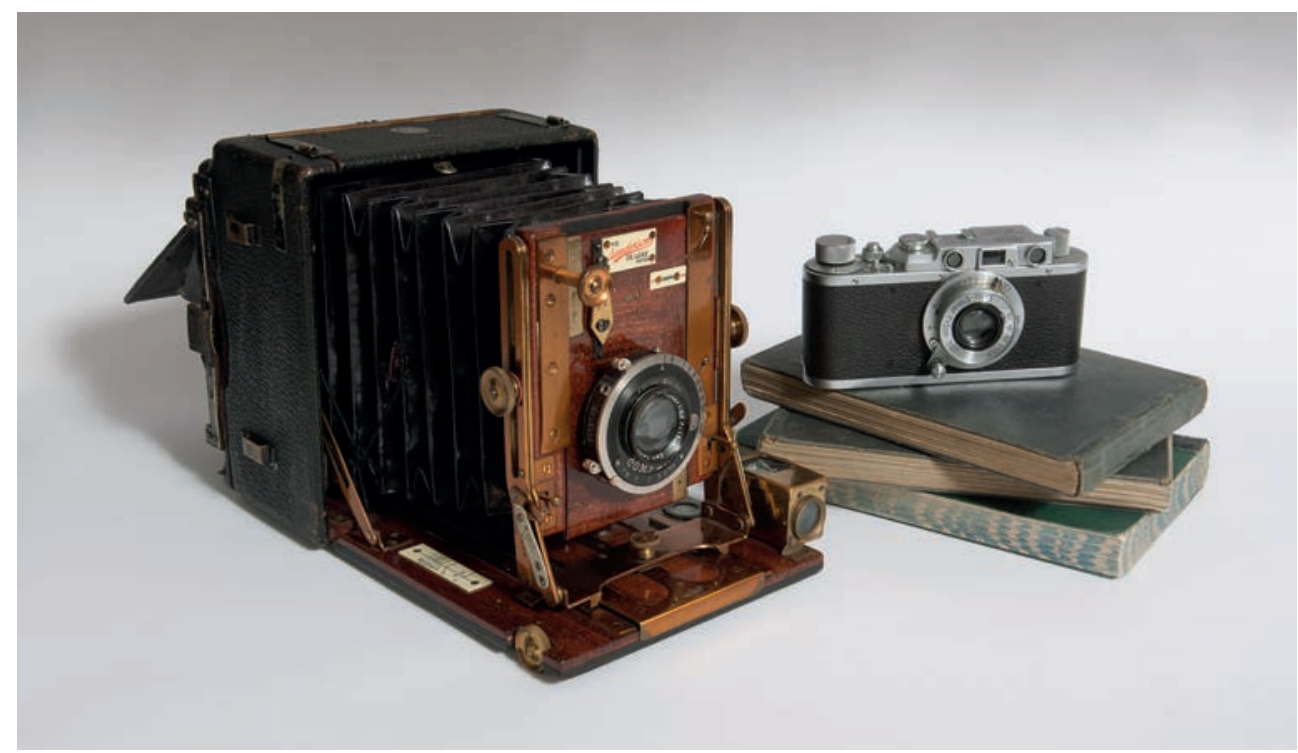

ILLUs 7 Angus Graham's notes and diary were meticulous, making it relatively straightforward to identify the many thousands of photographs taken on these surviving cameras, and to trace his progress around Scotland. DP 208545 (c) Crown Copyright: Historic Environment Scotland

five and fifteen exposures, with two or three buildings recorded each day. Despite a cautious approach to architectural description, Graham did venture a paper on the 17th-century painted ceiling at St Mary's Church, Grandtully - at that time poorly protected by a deteriorating roof - and another on the wall painting at Traquair House (Watson \& Graham 1942; Graham 1943) (Illus 8). ${ }^{40}$

Emergency photography aside, the Commission's collection was also at risk of destruction. Since the Treasury had refused to sanction the cost of publishing Orkney and Shetland, six bound copies were distributed for safekeeping. ${ }^{41}$ Other Inventory material, including the well-advanced Edinburgh typescript, was stored in the Museum's vault or at Glenormiston House, Innerleithen. ${ }^{42}$

Although Graham was confident that the early buildings in areas at risk had been covered during the summer, he argued that the programme for 1942 should capture additional images of buildings that had already been inventoried, seeing the opportunity for improving the Commission's overall record. ${ }^{43}$ A year later, the photographic record of houses and castles seemed to have reached 'a point at which the returns to be gained from further expenditure of time and money will diminish markedly' ${ }^{44}$ In all, some 2,200 photographs were taken of some 280 buildings - a large photographic collection at the time and an important contribution to the Commission's nascent archive (Illus 9). The process of collecting material simply as a record, rather than as a means to the production of a report, was something of a departure and paved the way for the modern notion of a National Collection, quite apart from that of a National Survey.

The success of Graham's architectural programme resulted in a suggestion from the Treasury that he should carry out a similar task in the north of England, which eventually resulted in the collection of some 3,361 images of buildings in Cumberland, Durham and Northumberland, taken between 1943 and $1944 .{ }^{45}$ These photographs were subsequently deposited with the National Buildings Record in Oxford, and now sit within the archive of English Heritage. ${ }^{46}$ A paper by Graham on Northumbrian 


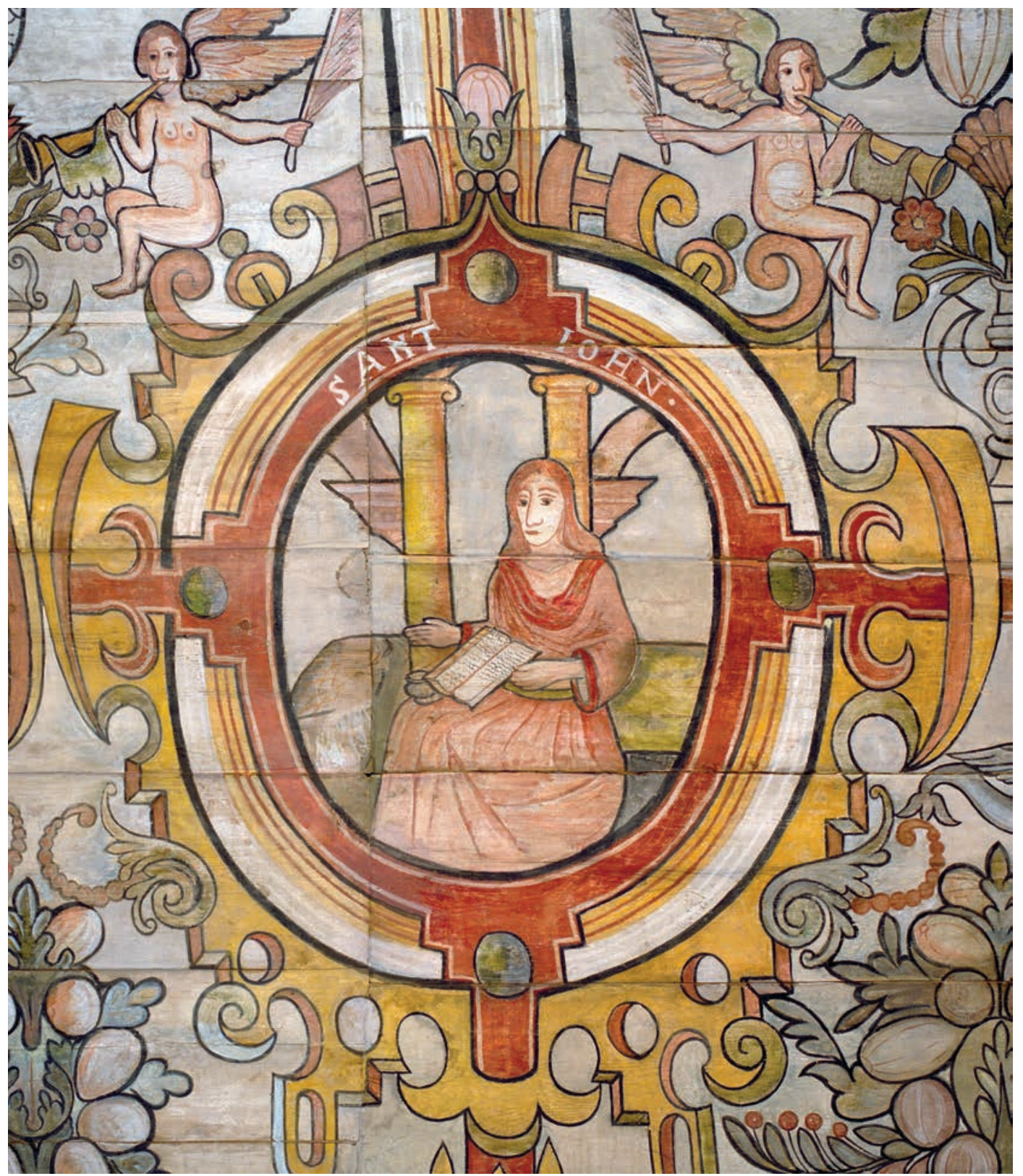

ILlus 8 St Mary's Church, Grandtully, Perthshire, 2004. This beautiful roof is decorated in an extensive and complex scheme dating to the 17th century, researched and described in detail by Angus Graham in 1943. SC 1242547 (C) Crown Copyright: Historic Environment Scotland 


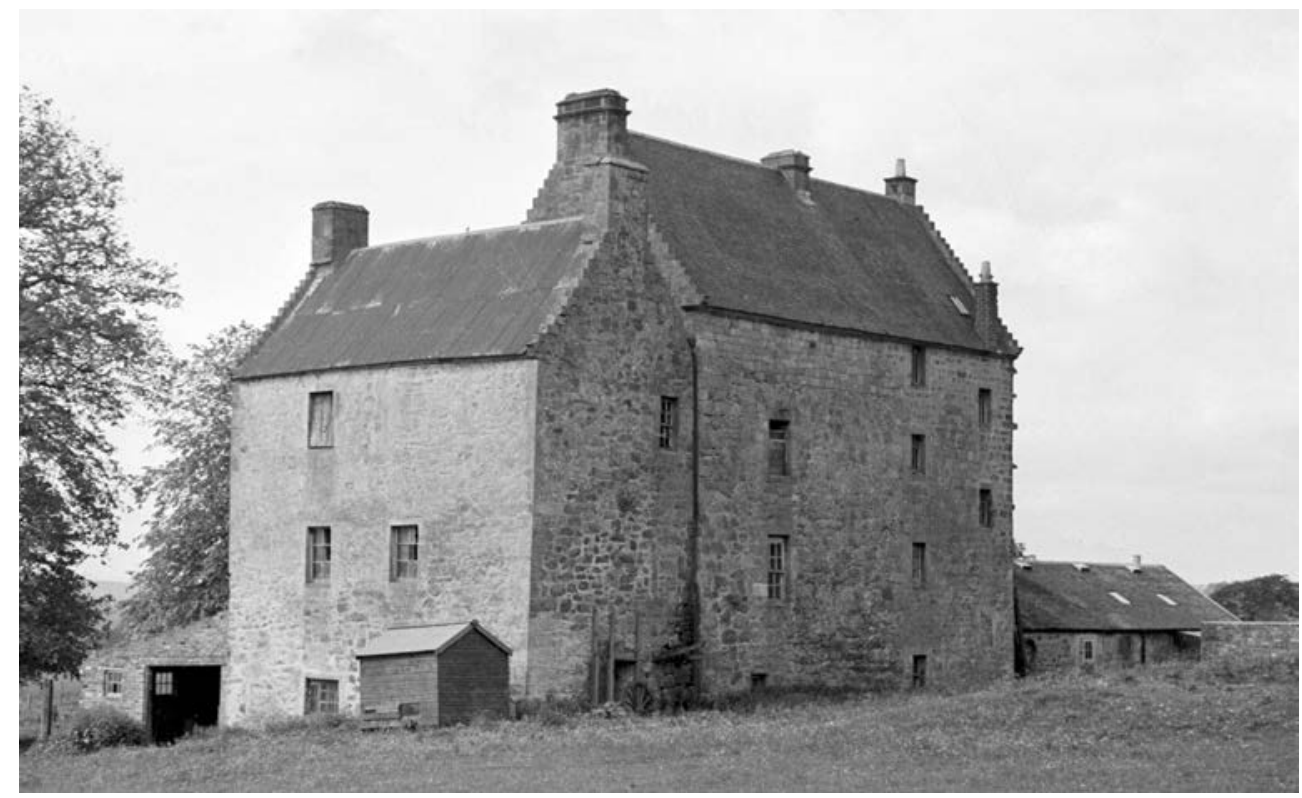

ILlus 9 Westshield House, Lanarkshire, 1943. This 17th-century building was demolished more than 30 years ago, making the photographic record invaluable. SC 1436151 @ Crown Copyright: Historic Environment Scotland

'peles' was read to this Society in March 1947 as a direct result (Graham 1948).

\section{CHILDE'S APPOINTMENT AS COMMISSIONER}

While Graham's emergency work continued, both he and Watson proceeded with the Inventory programme and changes continued within the ranks of the Commission itself. ${ }^{47}$ Not long after the war had started, Sir George Macdonald's health failed and he finally died in August 1940, aged 78. The role as chairman was filled from the ranks of the Commission by Sir John Stirling Maxwell (1866-1956), 'an eminent figure in Scottish public life' and the son-in-law of the Commission's first chairman (Dunbar 1992: 18). With the deaths of Callander and Macdonald archaeological expertise on the Commission was much reduced and the circumstances that had led to the rejection of Childe were now completely reversed. In the intervening years Childe had continued in his role as Professor at Edinburgh, although this burden lessened in the war years. His contribution as this Society's editor carried through, as did a role as interim Director of the National Museum of Antiquities between 1944 and 1946, after the death of Arthur Edwards (Ralston 2009: 63-4). While excavations were fewer in number in wartime (see Ralston 2009: 74-5 for a comprehensive list), his writing of syntheses continued apace (1942b; 1944a).

Professor Bryce moved to suggest Childe for appointment at the meeting of the Commission on 4 November $1941 . .^{48}$ Given the acrimonious history of earlier years, it cannot have been without irony and some humour that Childe's name was agreed unanimously, Sir John writing later that the Scottish Home Department must be 'hopelessly out of touch with the realities of Scotland if they do not know he is the right man for the job'. ${ }^{49}$ As the Commission's Secretary, Graham was given the task of taking forward the suggestion to the Scottish Home Department, but initial correspondence in early January seems to have been unsuccessful, and a renewed effort was required: 
20 January 1942. Spent most of the day on a letter to T McQueen Walker about V G Childe's appointment to the Commission. Had lunch with Maclehoses, meeting Lady Seaton and Lady Sands. Quite heavy snow lying. Continued work on propaganda letter for USA. ${ }^{50}$

This extraordinary letter (Appendix 1) was written to answer 'certain points' raised in telephone conversations with the Scottish Home Department's McQueen Walker, but coming from an altogether higher level. ${ }^{51}$ While it served to placate some concerns, the Secretary of State's office still moved to gain information on other candidates, which included Dr William Croft Dickinson (1897-1963) and Professor Vivian Hunter Galbraith (1889-1976) in the first instance, though at least six others were considered. ${ }^{52}$ A first port of call seems to have been Sir John Mackay Thomson (1887-1974), Secretary of the Scottish Education Department, who in turn consulted Sir Thomas Holland (18681947), principal of the University of Edinburgh, and Henry William Meikle (1880-1958), head of the National Library of Scotland. Meikle wrote a detailed note on Dickinson and Galbraith and offered the following on Childe:

I only know Prof. Childe officially and professionally, but there is no doubt that he is an archaeologist with a European reputation, the only one since Sir George's death ... I know from gossip that there are certain things against him. He is, for example, a Communist and that prevented his appointment to succeed Sir George as President of the Scottish Antiquaries. But there's a good deal of prejudice against him and his appointment would give the Commission a real standing ... I should plump for Childe but you will find it difficult, unless you are firm (!), to have him admitted into the family party such as the Commission is!! ${ }^{53}$

With little sign of movement, Graham turned to his chairman, Sir John Stirling Maxwell, who wrote directly to the Secretary of State on 30 March, reiterating some of the points Graham had already made. ${ }^{54}$ A sealed envelope marked 'Confidential' and filed with the papers on appointments to the Commission includes two further handwritten letters from Stirling Maxwell, dated in the following two weeks.
These describe in some detail an accusation by the Edinburgh police that Childe was a Communist and the results of correspondence by the Commission's chairman with the Edinburgh and Glasgow police, as well as with Major Peter Perfect, MI5's Regional Security Officer in Edinburgh. Stirling Maxwell was successful in finding out the root of the official concerns in Scotland about Childe's Communism: his attendance at a relatively innocuous party held in Edinburgh in July 1936 to honour the Soviet Ambassador Ivan Maisky and his partner. A misreading of the original report led to Childe being labelled as a Communist by Glasgow police, but Stirling Maxwell managed to not only show that there was no 'direct evidence' against Childe, but to get Glasgow police to withdraw their statement, and Edinburgh police to confirm that they had 'nothing against Professor Childe'. ${ }^{55}$ Stirling Maxwell also corresponded with Major Peter Perfect, and he prepared a detailed note for the Secretary of State on their records. Again, much hinged on the mistaken statement by Glasgow police that Childe was a member of the Communist Party, but MI5 could not prove it and considered Childe to be 'of the progressive intellectual type but not dangerous'. Perfect confirmed in April 1942 that MI5 had 'no reason to take exception to Prof. Childe'. ${ }^{56}$

Stirling Maxwell's efforts with the police and MI5 seem to have finally provided enough material to satisfy the Secretary of State that Childe was the right man for the job, and he wrote to Childe on 23 April to offer him the role. In Childe's reply, drafted a day later, he wrote that he would be 'proud' to join and hoped he 'may be able to materially assist in the recording and conservation of the remains of our ancient and historic heritage'. ${ }^{57}$ Childe was formally appointed by Royal Warrant on 6 May 1942 (RCAHMS 1951: xviii), an outcome that was described by Graham as 'a most fortunate end to a tiresome business'. ${ }^{58}$

It is clear that the Secretary of State required evidence for Childe's appointment which satisfied any doubts over his expertise and manner, as well as his affiliation with Communist organisations. What is remarkable is the length to which the civil service went to find reasons 
(such as his modesty) not to appoint Childe to the Commission. Thus it fell to Stirling Maxwell (the Commissioner's chairman) to take the time to challenge the assertions and assumptions which had been so easily made by the police and MI5. To add yet another layer of intrigue, there is no question that some of Childe's time during the war was taken up with interests in the Soviet archaeology and Communism (Klejn 1994: 76-7). Also, while the MI5 file on Childe contains nothing specific for the period in question, there seems little doubt that both they and the Edinburgh police continued to consider him a possible Communist, although there is no evidence of active monitoring (Ralston 2009: 82; Lever 2015). ${ }^{59}$

\section{EMERGENCY ARCHAEOLOGICAL SURVEY}

A month later, in June 1942, a new proposal came forward to the Commission centred upon the creation of a record of archaeological sites in military training areas - probably in response to the fact that Polish artillery had already damaged a well-known chambered cairn (Graham 1981: 223). On 3 and 4 June, Graham 'helped J S Richardson [Ministry of Works] with lists of ancient monuments in training areas', ${ }^{60}$ and plans were afoot for a Commission survey just days later:

9 June 1942. Worked on preparations for tour, and interviewed A O Curle and V G Childe about continuing work for the Commission after autumn. Was instructed to write to the Chairman about inspecting military areas. Packed up, after cleaning a window with cellulose solvent. ${ }^{61}$

Graham also wrote directly to Lieutenant-General Andrew Thorne, Commander-in-Chief, Scottish Command (Barclay 2013: 11) explaining the situation:

The Commissioners understand that the War Department and the Ministry of Works and Buildings are making a joint effort to protect all ancient monuments in the areas now being taken over for training purposes, and are extremely glad to know that this is being done. They fear, however, that with the best will in the world a certain amount of damage is certain to be done by the troops, who can hardly be expected to recognise prehistoric earthworks, grave-mounds and so forth, especially as such descriptions of them as are received from the Ministry of Works and Buildings are likely to be meagre and their location perhaps not very definitely expressed. $^{62}$

A meeting with Colonel Mackenzie at Scottish Command resulted in agreement about the general approach and, by 7 July, a list of training areas and monuments therein had been made, prepared in the main from Ordnance Survey maps and articles in these Proceedings. ${ }^{63}$

Childe offered to take on much of the fieldwork himself, perhaps recalling his sentiments of 1939: 'that I can be of any use in the forthcoming catastrophe I don't now feel convinced and a retreat into rather than across the Atlantic seems most reasonable' (Green 1981: 87). His initial plan included the survey of the islands of Eigg, Muck, Mull and Rum as well as the Ardnamurchan peninsula, but it was Mull that proved the focus in July 1942. Childe visited about 50 sites in the company of a student, J H Burns, some eight years after an earlier visit. ${ }^{64}$ This represented the northwestern extent of the Emergency Survey, in part, perhaps, because of the limited training activity along the mainland coast and in part because the Outer Hebrides, Skye and the Small Isles had been covered by an Inventory relatively recently (RCAHMS 1928).

For the second foray, Childe joined forces with Graham and headed out for a trip to eastern Perthshire, with Graham at the wheel. ${ }^{65}$ While standing stones and stone circles were often straightforward to record, a day spent examining the medieval deer park at Buzzart Dykes led to a thorough factual description, but no hint as to its date or function (Childe \& Graham 1943: 45-9; Crawford 1949: 76-7; RCAHMS 1990: no. 216).

4 August 1942. Left Edin. in am with V G Childe. Lunched at Perth, with Mrs Stuart, and in pm inspected standing stones and stone-circles near Bankfoot i.e. Loak, Pitsundrie, Strath-head, Meikle Obney and Staredam. ${ }^{66}$ 
At Steed's Stalls, the pair described and surveyed 'indeterminate remains', innocent of the 1941 air photographs, which would show the site to fall within a Roman temporary camp (Richmond 1943; RCAHMS 1994: 83). A diet of standing stones, four-poster stone circles, cairns, a cupmarked stone and a fort was broken by the Barns of Airlie souterrain with its unusual carved lintel (Childe \& Graham 1943). Unenclosed settlements were also recorded that week, such as the hut circles at Black Briggs, but the car eventually failed them and they returned by train from Blairgowrie to Edinburgh, eight days after setting out. Work on cataloguing was cut short soon afterwards when Graham was called back to the field by the Ministry of Works:

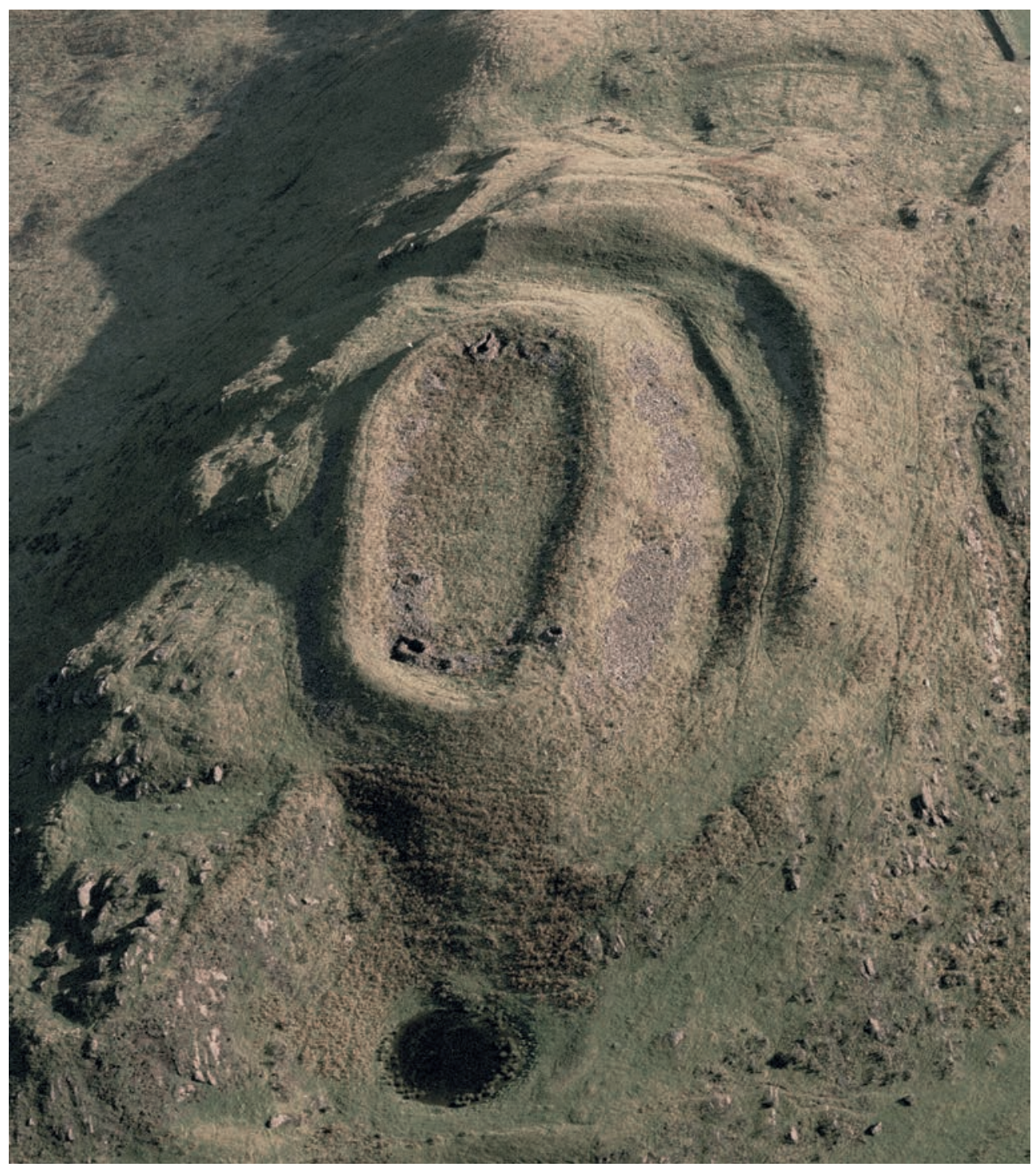

ILlus 10 Barry Hill, Perthshire, 1983. The extensive prehistoric fortification at Barry Hill was recorded in June 1942, but campaigns of photography, survey and description continued until and beyond 1990 when it was included in the RCAHMS survey of north-east Perth. SC385383 @ Crown Copyright: Historic Environment Scotland 
13 August 1942. Worked on photographs in am and called on Trickett at Ministry of Works. Hearing of urgent work at Barry Hill [Illus 10] and Turin Hill from J S Richardson, returned to Blairgowrie in pm in time for supper. Weather improving. ${ }^{67}$

Letters in the project correspondence files make it clear that Graham regularly communicated with Richardson and, on 21 August, he sent in a formal list of 17 sites recommended for protection out of a total of 114 visited. ${ }^{68}$ From August until late October, Childe and Graham went on regular field trips, usually working together but taking turns at notes and photography. Most days consisted of a straightforward round of prehistoric and medieval monuments that were shown on Ordnance Survey 6-inch maps or described in the literature, each being consistently recorded and occasionally photographed. Weather curtailed but did not stop fieldwork, the pair continuing their work on 15 September, despite the 'high wind and furious showers'. ${ }^{69}$ On occasion, they were richly rewarded: that very same day Cnoc Mhic Eoghainn, Ballimore, was recognised as a medieval motte, while a Late Bronze Age hoard discovered during the excavation of an ornamental pond at Ballimore House was removed for treatment to the National Museum of Antiquities (Childe 1943; Ralston 2009: 63). ${ }^{70}$ Graham took the opportunity to include some additional architectural subjects when the pair were far from the office, on one occasion 'spending a long time taking photographs in intervals of rain at Castle Sween'. ${ }^{71}$ Over 230 archaeological sites were visited in 1942, the pair moving through Angus (10), Argyll (69), Ayr (58), Lanark (14), Perth (85) and Selkirk (1). Their descriptions were complemented by 180 photographs and 34 sketch plans.

8 October 1942. Went to survey sites on Muck Water and Duisk, between Pinwherry and Barrhill. Showery day, with weather deteriorating in $\mathrm{pm}$. After lunch lost V G C owing to rendezvous being impossible by car; had encounter with bull and long fruitless walk, eventually finding V G C at Barrhill mainly owing to luck. Wrote letters in evening. ${ }^{72}$

During the following winter, Graham returned to his office schedule, processing the results of his emergency work by cataloguing the photographs and writing each site description. The day-to-day administration of the Commission and Society continued, as did his work on the Edinburgh introduction and articles for the Roxburgh County
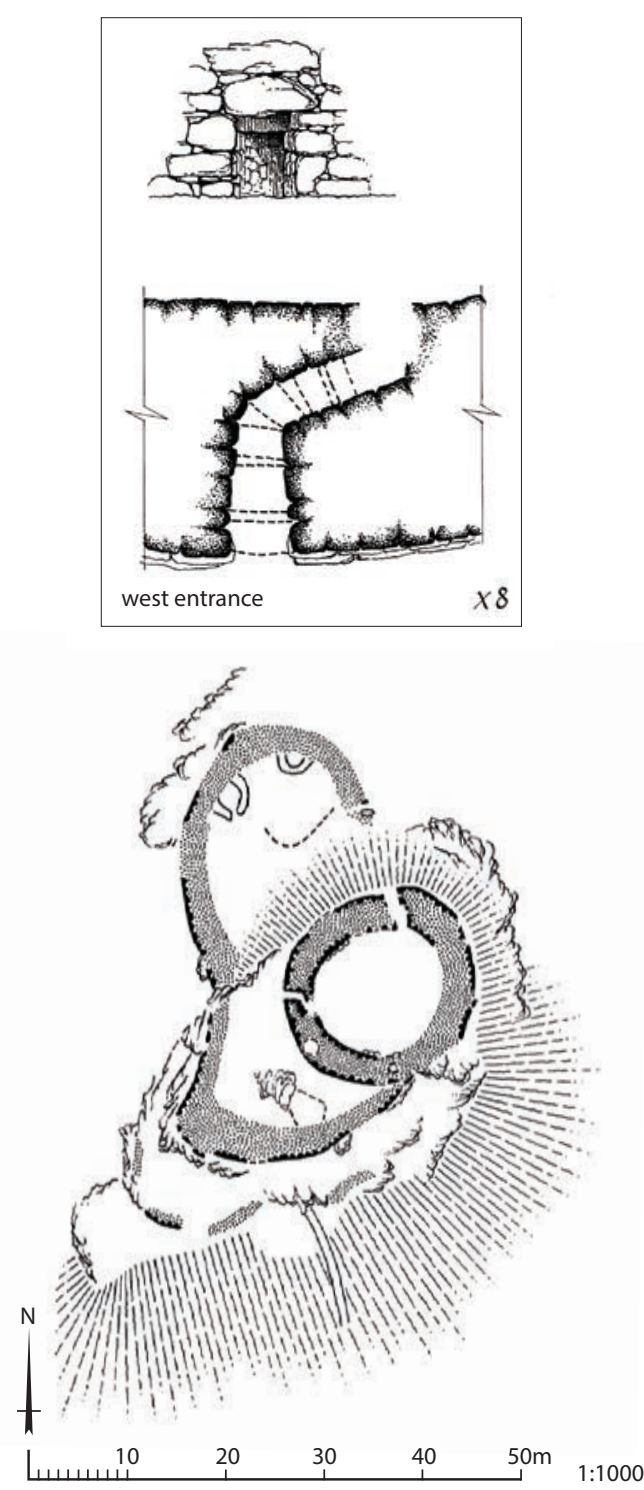

ILlus 11 Dùn a' Choin Duibh, Argyll. A sketch plan of Dùn a' Choin Duibh in Argyll was published by Childe and Graham in 1943, but the County Inventory relied on this new illustration prepared in 1984. GV006264 (c) Crown Copyright: Historic Environment Scotland 
Inventory. A paper jointly written with Childe was prepared in order to present new discoveries from the summer's fieldwork. It described a range of monuments of particular interest since they helped to demonstrate the geographical range of a known class, had particular or unique features, or simply raised interesting questions (Childe \& Graham 1943) (Illus 11). ${ }^{73}$ Mainly descriptive in character, the article sought to highlight sites useful in comparative studies, but some attempt was made to set the chambered cairns in particular within a regional group.

Fieldwork recommenced in May 1943 with a mixed economy of joint and individual trips. Graham visited the counties of Aberdeen (44) and Bute (17), while Childe returned to Mull and took in a small number of sites in Morvern and Lismore. During August and September the pair reunited to work in the North Highland Block, tackling parts of Ross and Cromarty (70), Inverness (79), Nairn (15) and Moray (18), working as far north as Strath Oykell. They were joined for short periods in the north by Cromartyborn William Mackay Mackenzie, Graham's predecessor as Secretary, as well as the historian Vivian Hunter Galbraith - both were appointed as Commissioners in February 1943. The northern counties of Caithness and Sutherland had been covered by County Inventories some 30 years earlier (RCAHMS 1911a; 1911b) when much of the fieldwork had been undertaken solely by A O Curle. Childe and Graham clearly felt that further work in the far north could not be justified - especially as revisiting sites in Orkney and Shetland would have simply repeated the County Inventory programme that had been completed in 1937. Childe's wartime activities in Orkney were, it seems, unconnected (Ralston 2009: 63). By the end of 1943, the pair had recorded more than 636 archaeological sites (RCAHMS 1951: xxxviii) including 150 cairns, 40 chambered cairns, six ring cairns and six long cairns (Illus 12). In addition, over 50 duns and 50 forts could be added to a list that included at least nine brochs, 12 hut circles and nine souterrains. During the accumulation of this impressive catalogue, the duo had been involved in more than one memorable incident, which Graham recalled in his inimitable style:
27 June 1943. Turned back from surveying cairns in Pentlands by danger of getting shot, and spent balance of day surveying earthwork near Newbigging [Weston henge]. Tea at W. Linton, and returned to Edinburgh afterwards.

27 September 1943. In am visited a fort and a cairn field near Grantown; V G C lost his watch. In $\mathrm{pm}$, collected bog myrtle and rowans to take back to Edinburgh. Very cold day, with snow on Cairngorms. ${ }^{74}$

In October 1943, the Commissioners agreed to the publication of a paper discussing an unrecognised group of chambered cairns, "pending the issue of relevant inventories in a comparatively distant future' (Childe 1944b: 26). ${ }^{75}$ In this article Childe described some 26 cairns which 'to professional surprise' filled in a gap in the distribution between the Pentland group to the north and the Clava group to the south (Henshall \& Ritchie 2001: 24-5). This included photographs from the survey and a series of Graham's plans which illustrated the chambers alone (Henshall 1963: $335,347,357,377)$.

Although a small number of brochs were visited during the Emergency Survey, Graham's 'enormously useful' study of the buildings - published just a few years later - was not directly related to this work (Graham 1947a; Armit 2003: 55). His analysis of broch material began in November 1941 and drew upon the Commission's pre-war survey of the main broch areas (RCAHMS 1946, v1: xvi). ${ }^{76}$ Much in the manner of his relationship with previous Commissioners, he consulted Childe regularly and there is no question that the pair discussed brochs and other archaeological matters at length during their forays. A less comprehensive but no less valuable paper was published by Graham in 1959, discussing 'Cairnfields in Scotland' and drawing on examples recorded in 1942 (Graham 1959: 10, 15). It is even arguable that the work undertaken by Childe and Graham in Argyll in 1942 and 1943, when they recorded some 155 sites - almost twice that in any other county partly informed the decision by the Commission to focus on Argyllshire from 1968 (Geddes 2013: 384). The preference of the military to train in the hills and glens of Argyll has thus had an 


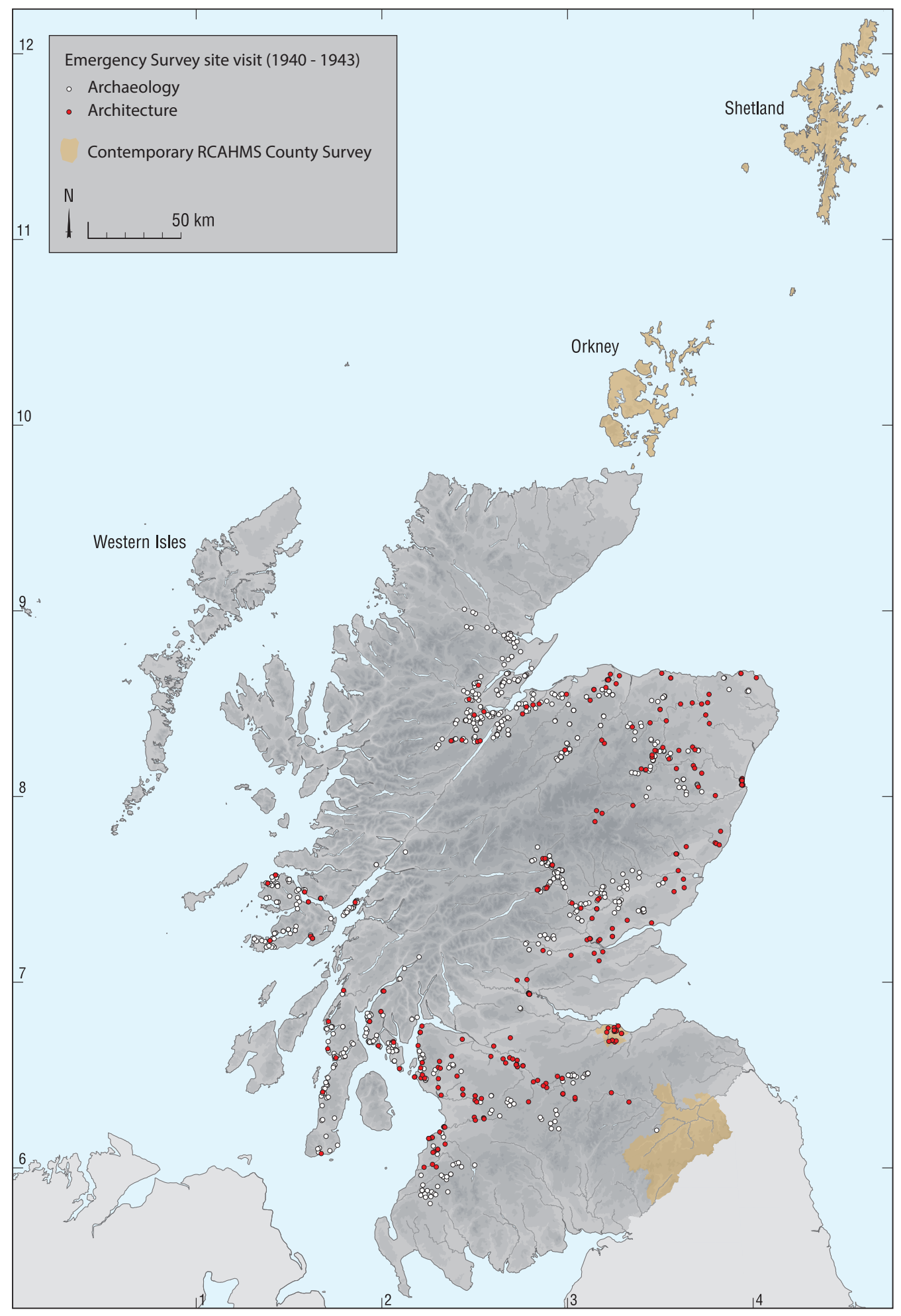

ILLUS 12 Distribution map indicating the large area covered by Angus Graham and Gordon Childe between 1940 and 1943. GV006258 (C) Crown Copyright: Historic Environment Scotland 
unexpected impact on archaeological survey in Scotland.

Graham and Childe clearly conceived their Emergency Survey to have relatively clear objectives. The essential model, developed from the existing RCAHMS County Survey practice, was of a topographic study that responded to areas of the country used in training exercises, employing as its primary sources the record of antiquities made during the 6-inch Ordnance Survey and published work. ${ }^{77}$ From this was developed a list of targets that were summarily visited, recorded and ticked off. A lack of vertical aerial photography prevented any form of modern remote-sensing, while a physical limit to the ground the two men could cover on foot clearly prevented any attempt at a 'walk-over survey' in the modern sense.

Where Graham's notes were meticulous and detailed, Childe's were skeletal and the surviving notebooks present a remarkable contrast - in some instances, even identifying the site Childe was noting has proved well-nigh impossible. Despite this, both men produced carefully structured and detailed manuscript descriptions in the Commission's house style, often writing them up at night following their day in the field. Each had a camera, Graham the Commission's 1937 Leica, Childe a camera which was probably his own. Again, there is a marked contrast in the quality of their photography - Graham's are usually in focus and pay attention to composition and light, Childe's are regularly blurred, which is understandable given his poor eyesight. In each case, the images survive as an early and often primary photographic record, individually filed in envelopes, sometimes with handwritten notes. The brief sketch plans the pair prepared are often rudimentary, Graham describing Childe's draughtsmanship as simply 'bad' (Graham 1981: 224). His own drawings, careful measured sketches prepared with a clinometer and surveyor's compass, were of a much higher standard, and were generally drawn up to illustrate a description. Particular care was taken with the chambers in cairns - the specific alignment and the details of the architecture being recognised as of especial importance. A good indication of Graham's true attitude towards Childe's notes can be gleaned from a handwritten note from 1949:

Only a few pages of the foregoing material is in typescript, and typing the rest would be a formidable task as much of it is in V G C's handwriting. Again, much of what he wrote was written hurriedly, and would consequently require extensive editing. ${ }^{78}$

\section{CHILDE'S RESIGNATION AND DEVELOPMENTS THEREAFTER}

It was not until the autumn of 1946 that the four staff of the pre-war Commission were reunited, but progress continued to be significantly delayed by an enforced change of premises, the advancing administrative burden and interminable difficulties concerning publication through the Stationery Office. ${ }^{79}$ The completion of Roxburgh and Selkirk became the priority and Childe, clearly seen at this stage as an authority on field survey, was 'good enough to take $\mathrm{Mr}$ Calder and Mr Steer on a tour of some important prehistoric monuments, in preparation for their field work of $1947^{\prime}{ }^{80}$ This proved to be one of his last contributions, as a decision to move to the Institute of Archaeology in London presaged his resignation from the Commission (RCAHMS 1951: xxix). In doing so, he remarked in his brief resignation letter that:

this particular sort of service can best be rendered by one who is normally resident in Scotland and has consequently better opportunities for visiting sites and can do this and attend meetings of the Commission without burdening the taxpayer with the heavy cost of railway travel from one capital to another. ${ }^{81}$

Little is known of the attitude of Commissioners and staff to Childe's resignation in October 1946, but it is clear that he and Graham retained a strong sense of mutual respect. Recalling Graham, Childe 'carried away the greatest admiration for his massive learning and also for his astonishing capacity for withstanding physical fatigue - the more remarkable for a man of rather poor physique' (Green 1981: 88). Graham, for his part, recalled a man with 
a 'powerful visual memory and vast practical experience', enriched by 'a logical scheme which widened the whole of the prehistoric horizon' (Graham 1981: 224).

Together, the pair had created emergency records of more than 636 archaeological sites across Scotland, the majority of which were prehistoric. $^{82}$ Working to a consistently high standard, they amassed a suite of manuscripts, sketch plans and photographs that was invaluable at the time and also retained its value, eventually being edited, typed and bound for the Commission's library in 1960. Coupled with Graham's photographic survey of 280 buildings, the archaeological survey was a significant contribution to the National Collection, equal in significance and size, if not perhaps in detail and scope, to many of the pre-war County Inventories. More importantly, these wartime projects set in train a close relationship between RCAHMS and programmes of work focused primarily on 'rescue', while continuing an obviously strong relationship between the recording programmes of RCAHMS and the protection offered through the Ministry of Works. For the Commission's archaeologists, much of the 1950s was taken up by the Survey of Marginal Lands (Geddes 2013; RCAHMS 2015: 30-3), a specific response to increased agricultural improvement and afforestation. 'Special Surveys' prompted by new discoveries or threat of damage began explicitly in the late 1940s and continue to this day (eg Calder \& Steer 1951). Later developments, such as the RCAHMS Afforestable Land Survey begun in 1989 (eg RCAHMS 1998; 2001) thus had deep roots in a past of rescue recording. The notion of recording in advance of damage or destruction also became of central importance to the rolling architectural programmes of the office from at least the late 1960s, with the Threatened Building Survey of listed buildings continuing as a major strand (Hay 1977; RCAHMS 2015). Membership of the Commission also continued to evolve: Childe was replaced by William Douglas Simpson in 1946, James Curle by Professor Ian Richmond in 1944, Bryce by Professor Stuart Piggott in 1946 (Illus 13). This new crop would have a considerable influence on the organisation's development, although the results were not apparent until the publication of Roxburghshire in 1956.

Just after Childe's resignation, readers of the 1947 Antiquaries Journal would have found an interesting brace of reviews, with one exploring the merits of Scotland Before the Scots (Childe 1946), while the other critiqued the Orkney and Shetland County Inventory (RCAHMS 1946). In the first, Angus Graham soberly assessed Childe's attempt to 'apply the Soviet method to the data of Scottish prehistory'. He prepared the review in November 1946, just days after Childe's retirement from the Commission, and during a busy month which included fieldwork on Roman roads, further work on brochs and a couple of meetings with Stuart Piggott and his wife Peggy. ${ }^{83}$ Graham wrote that the general reader at least cannot fail to welcome the author's straightforward method of classification' (1947b: 89). While staying within the acceptable confines of politeness, he did offer one specific criticism relating to a particular physical trait of heel-shaped chambered cairns, which did not 'stand on platforms at all' (Childe 1946: 97; Graham 1947b: 89-90). A better juxtaposition of Graham's meticulous recording and Childe's panoramic view could hardly be found.

In the second review, the new Commissioner Stuart Piggott expressed unguarded and pointed criticism, the Chairman having 'left him free to make any criticisms as he thought fit of a production in which he was no way connected' (Piggott 1947: 93; cf Marwick 1947). His disapproval, however, was targeted on the 62-page Introduction, the combined effort of the staff, the Commissioners and the Chairman; 'While their objective fieldwork and recording is beyond praise, the Commissioners, unfortunately, contrive to give the impression that the prehistoric antiquities of Orkney and Shetland have not been dealt with by prehistorians' (idem). Specifically, he argued that the summaries of chambered cairns, stone circles and brochs treated them as 'typological abstractions unrelated to contemporary cultural movements', that it did not reflect contemporary approaches (such as Childe's Prehistory of Scotland), and said too little on age, cultural 


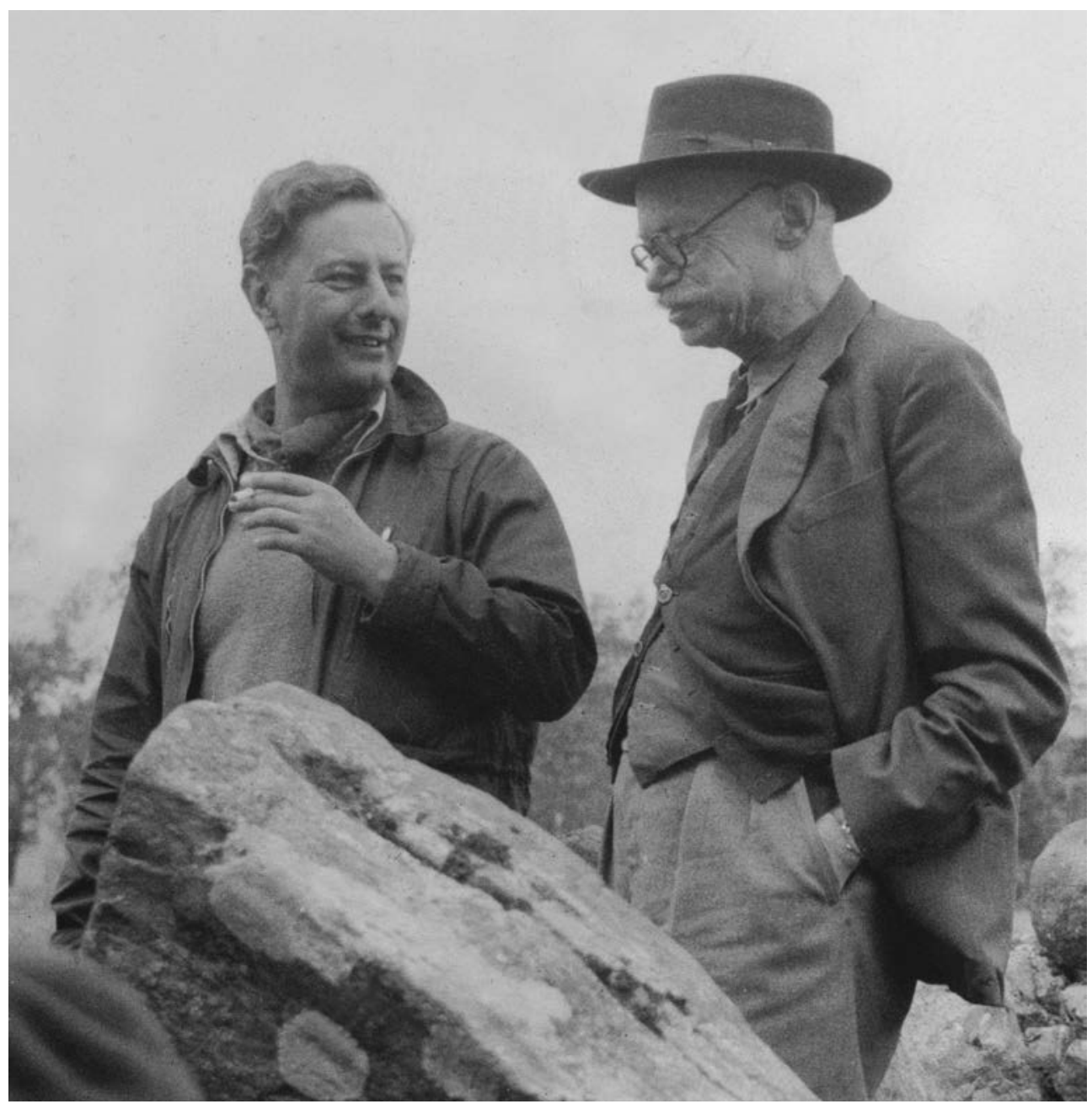

ILLus 13 It was Stuart Piggott (left) rather than Gordon Childe that was to have a profound effect on the work of the Royal Commission. SC428929 (c) courtesy of Historic Environment Scotland (Allard Johnson Collection)

affinity, or on their broader significance in the Scottish and European context. To the general reader, this may have seemed peculiar when Childe was himself a Commissioner from 1942 until 1946, but the Inventory failed to explain fully its long gestation, nor the process and methods by which its conclusions had been drawn; and Childe, of course, was thanked only for 'material contributed' (RCAHMS 1946, v1: $\mathrm{xv})$.

Piggott did recognise that the Commission was successful in providing 'an illustrated regional survey [that] has permanent value as a work of accessible reference' (1947: 92). Even now, some 60 years later, many of the descriptions and plans remain useful, and where subsequent discoveries have not moved the goal posts, much of the Inventory proper retains its serviceability. That said, Piggott's comments highlight a tension between the collection of reliable information and the handling of that material within a contemporary theoretical framework - a tension that is always difficult to resolve to the satisfaction of all. He was also correct to imply that an 
organisation that relied upon Commissioners appointed for life and a small dedicated staff that stayed within its confines for decades might suffer from a certain myopia. Childe, as we have seen all too clearly, was not able to exert control over the results of the Inventory, but he certainly had some influence. While Sir George Macdonald may have been right in his belief that RCAHMS had sufficient archaeological expertise within its ranks in 1938, the rebuttal of Childe simply served to drive a wedge further between Scotland's leading prehistorian and the national survey body. Authorship by the existing committee of retired experts and administrators undoubtedly ensured a high degree of accuracy and care, but it also eschewed the projection of a contemporary theoretical ethos.

The improved results in the Commission's next County Inventory, Roxburghshire (1956), owed much to the involvement of Professors Piggott and Richmond in both fieldwork and analysis, as well as to the thorough study of newly available vertical aerial photography, and the execution of a programme of excavation by or with RCAHMS staff (eg Piggott 1950; RCAHMS 1956: xxv, xxvi, 16; Steer 1958; Feachem 1959). Reviews of Roxburghshire, while highlighting new problems of scope, were generally positive, and the architectural historian Howard Colvin noted that 'it would be hard to find any locality in the British Isles whose antiquities have in general been surveyed better' (1957: 680; see also Radford 1959).

\section{CONCLUDING REMARKS}

The Royal Commission's survey work in Orkney and Shetland between 1928 and 1936 came at an exciting and dynamic time, and the creation of an introductory synthesis to their report that was both succinct and accurate proved challenging, particularly given the pace of change and discovery. Fundamental differences of opinion between J G Callander (the leading prehistorian on the Commission) and V G Childe (the excavator of prehistoric settlements at Skara Brae and Rinyo) placed the Commission's Secretary, Angus Graham, in a difficult position - he ultimately had to negotiate a path between the strongly expressed views of both experts, while relying for the final word on his Chairman, Sir George Macdonald, and the other Commissioners. Tensions between the Commission and Childe came to a head in 1938, when Childe was passed over as Callander's replacement. While this was ostensibly because archaeology was well represented on the Commission, it was nonetheless a snub. An about-face in 1942 resulted in a long tussle between the Commission and the Secretary of State for Scotland over Childe's appointment, the Commission's Secretary and Chairman relentlessly arguing with the sometimes obscure logic of the civil service, which had clearly been informed by a concern about Childe's political leanings. The Commission's persistence, and in particular the fact that their chairman secured confirmation from the police and MI5 that they did not have evidence to consider Childe a threat, secured his appointment. The fact that, during wartime, the civil service went to some lengths to avoid the appointment seems remarkable, although war may have provided the precise justification.

When Childe was finally appointed in May 1942, the text of the Orkney and Shetland volume had long been with the printers while work on the City of Edinburgh, principally an architectural study, was well advanced. Had he been appointed in 1938 rather than 1942, the reports may have been rather different. Childe's efforts as Commissioner were thus focused on the gathering of information through fieldwork, and in this he joined with the Commission's Secretary, Angus Graham, to make an 'emergency record' of archaeological sites in military training areas. Emergency recording of architectural subjects through an extensive photographic survey was already well underway, but the archaeological work of Childe and Graham in 1942 and 1943 was more comprehensive detailed descriptions, photographs and sketch plans were produced of some 636 monuments. The survey was unusual in placing the creation of 'records' and collection material as its principal outcome, rather than the normal production of an illustrated report and gazetteer. This decision, 
however, was not Childe's, but was developed by the Commission and the Scottish Home Department as an appropriate response to the wartime context.

But what of the archaeological sites themselves? Given the raison d'être of the project, the fact that only about $3 \%$ of them have subsequently been destroyed or even severely damaged is pertinent. Of those that have suffered, most have been affected by afforestation, but in one case, a cairn was bulldozed for a piggery, while in another, a standing stone was subsumed within field clearance. Most famously, the duns at Aldclune were excavated in 1980 under difficult conditions prior to the re-routing of the A9 road (Hingley et al 1997: 407), while the fort at Carwinning Hill was excavated in advance of quarrying (Cowie 1977; 1978). Almost 30 sites (about 5\%) have been partially excavated since 1945 (eg Piggott 1956; Martlew \& Ruggles 1996; Caldwell et al 1998), while a further 30 have been subject to some form of archaeological evaluation.

While excavations have been relatively rare, over $90 \%$ of the archaeological sites were visited by the Ordnance Survey's Archaeology Division between 1947 and 1983, resulting in succinct descriptions and small-scale plans (see Bowden \& Mackay 1999 for a summary). Later survey work by RCAHMS has been equally comprehensive (eg RCAHMS 1971; 1980; 1981; 1990; 1994; 2007). Angus Graham always argued that material collected during the war would prove useful to the office in the preparation of subsequent County Inventories, but the passage of time, a changing context and developing methods and techniques, meant that each subsequent publication has relied on more recent visits, building knowledge iteratively on the material prepared between 1942 and 1943. Since then, some 70\% of the sites included in Graham and Childe's archaeological survey have been recorded in more detail by RCAHMS. Some 150 have been surveyed and 120 covered by aerial photography. Surveys by other commercial or community groups add perhaps another 40 sites to this total. In her comprehensive review of chambered cairns, Audrey Henshall included 49 of the sites recorded by Graham and Childe, and drew on their sketch surveys (eg 1963: 376-7; 1972). The present study did not extend to a comprehensive review of subsequent architectural programmes, but the impression is that the majority of the architectural subjects have also been re-photographed, and in some instances surveyed and described in detail.

Childe's tenure from 1942 to 1946 was unusual for the Commission in that both Orkney and Shetland (1946) and Edinburgh (1951) were largely complete, but publication was delayed by factors outwith their control, while the work underpinning Roxburgh (1956) and Selkirk (1957) was still to be significantly enhanced. The war, perhaps as one might expect, had a profound effect on RCAHMS, causing severe disruption that affected every aspect of their work, from accommodation to staffing, equipment, printing and logistics. But all clouds have a silver lining, and the wartime experience of Kenneth Steer in particular, with the newly available air coverage, was to revolutionise their fieldwork and synthesis from the late 1940s (Geddes 2013). On a similar note, while the loss of Macdonald, Bryce, Callander and the Curle brothers was undoubtedly a blow, new voices emerged, and Professors Stuart Piggott and Ian Richmond amongst others were to make their own unique contributions, not only to RCAHMS, but also to Scottish archaeology as a whole. Graham, the quiet man in this story, continued to work on Scottish antiquities well into the late 1970s, more than 20 years after his retirement in 1957, the year of Childe's tragic suicide.

\section{ACKNOWLEDGEMENTS}

The digitisation of some 1,389 images was undertaken by colleagues in HES Survey and Recording: Tahra Duncan, Zoe Gibson, and Derek Smart, with the co-operation of Anne Martin. The distribution map was carefully prepared by Georgina Brown, while the 1984 plan of Dùn a' Choin Duibh was prepared for publication by Alison McCaig. Comments and suggestions were received from 
Oscar Aldred, Piers Dixon, Stratford Halliday, Anna Ritchie, Richard Sobolewski, Jane Thomas and, finally, Adam Welfare to whom particular thanks are due. Two anonymous referees kindly provided detailed commentary on an earlier draft of this paper, and amendments made thereafter strengthened it greatly. Thanks are also due to Catherine Aitken, Managing Editor, who handled the iterative process with care.

\section{APPENDIX ${ }^{84}$}

20th January 1942 Private and confidential. T McQueen Walker Esq. Scottish Home Department St Andrew's House Edinburgh 1

Dear Walker,

I have been thinking over our telephone conversation of this morning, in which you told me of certain points which had been raised in connection with the suitability of Professor Childe for appointment to this Commission. As far as my own personal opinions are concerned, these points may be dealt with very readily. I will deal with them one by one.

1. That as a prehistorian, Professor Childe's interests lie in earlier periods than those which the Commission is concerned. Reference to the Commission's Royal Warrant will show that it is concerned with monuments dating from the earliest times to the year 1707 .

2. Why does the Commission require a prehistorian at all? In so far as the answer to this is not implicit in the wording of the Royal Warrant just quoted, I may point out that the enormous majority of our Scottish ancient monuments are of prehistoric date and that the Commission must be organised accordingly. For example, of approximately 1750 monuments inventoried in Orkney and Shetland, some 520 may be classed as historic or protohistoric and the remaining 1230 , representing about 70 per cent., are prehistoric. The work and procedure of the English Commission is no guide whatsoever in this matter, as in England the conditions are, roughly speaking, reversed.

3. That he is too modest and shy to make a useful member of the Commission. While Professor Childe's manner is no doubt of the unassuming kind that befits a great scholar, it would be quite wrong to suppose that he is not an active and vital member of scientific bodies. $\mathrm{He}$ is certainly one of the moving spirits of the Society of Antiquaries of Scotland, both in respect of its policy and direction (as a member of the Council) and in technical discussions of papers read at its meetings. The Society of Antiquaries of London and the Prehistoric Society, to mention no others, have likewise seen reason to make use of his services at various times in one office or another.

4. That he is not a Scotsman. I hope most sincerely that the Commission is not to be precluded from obtaining the benefit of the best talent available on account of the mere accident of birth. The adoption of any such principle would spell disaster to the efficiency of its work. It is true that Professor Childe was born in Australia, but it is equally true that he is now one of the two leading authorities on Scottish prehistory. His chair at Edinburgh University is surely sufficient guarantee of his standing in his adopted country.

5. That he has no experience as a chairman. The question of his possible future appointment as chairman has not yet arisen, and I submit that it could well be left out of consideration for the present. I have seen him conduct a meeting with perfect efficiency, and believe that he has served as President of the Prehistoric Society; but in view of the fact that he would be the junior member of the Commission, I do not believe that the question of his suitability for the chairmanship would arise for some time, supposing a vacancy occurred.

6. Other possible candidates. The possible alternative gentlemen whose names you mentioned are undoubtedly most suitable for the appointment, and they and others have been before my mind for some time as future choices. It is a question, however, who should be taken first, and in view of our present situation I do not hesitate to say that it is Professor Childe who is needed at once, while we can afford to wait for the others until further vacancies arise. Perhaps I omitted to tell you that, when the Commissioners at their recent meeting decided to instruct me to make an unofficial move for the filling of the present vacancy, their desire to secure the appointment of Professor Childe as their colleague was not only unanimous but very warmly expressed. 
Nobody, of course, knows more about the Commission's work than Dr A O Curle, who was its first secretary and is now its oldest member but one. He is often to be found at the New Club, and if Sir Horace Hamilton required any further assistance - particularly in respect of Point 2 - I have no doubt that Dr Curle would quickly be able to satisfy him.

Yours sincerely,

Angus Graham

Secretary

\section{NOTES}

1 In addition to the Emergency Survey of 1942-3, this number includes a tally of the 13 inventories published between 1909 and 1951, which present pre-1945 activity.

2 These five were joined on the Commission by Sir John Stirling Maxwell (1866-1956, appointed 1934) (the nephew of the Commission's first chairman), Sir Iain Colquhoun (1887-1948, appointed 1934) and James Archibald Morris (1857-1942, appointed 1932) (RCAHMS 2015: 158). A O Curle was the Commission's first Secretary, undertaking the bulk of fieldwork from 1908 to 1912 (ibid 7-27). Callander took on the role as RCAHMS archaeologist from 1913 until 1919.

3 RCAHMS Correspondence file (1935): no. 41, Sir George Macdonald to Secretary, Civil Service Commission, 13 June 1935 (with enclosed Report of Selection Board); see also no. 33.

4 Graham's diary (Ref MS 36/24/7): 23 April 1935; Graham recalled that it was A O Curle who told him of the vacancy (1981: 227), and he had certainly known A O Curle from a young age (Gordon 1990).

5 Graham's diary (Ref MS 36/24/7).

6 Graham's diary (Ref MS 36/24/7): 9 October 1935; 5 March 1936.

7 There is not the opportunity here to examine the interaction of the Commission and the Ministry of Works in any detail.

8 Graham's diary (Ref MS 36/24/7); Peter Moar (c 1888-1983) was a Lerwick taxi driver and amateur archaeologist who assisted RCAHMS staff over many years (RCAHMS 1946, v1: xvi; Moar 1948; Calder 1965: 37; Anna Ritchie pers comm).
9 RCAHMS Minute Book: 16 April 1935; 8 October 1935; Graham's diary (Ref MS 36/24/14): July 1938; such was the impact of Corrie's illness that the Commission eventually successfully lobbied for the creation of a new post as assistant archaeologist. Kenneth Steer was appointed in July 1938, just weeks before Corrie's death (Dunbar 1992: 15; RCAHMS 1946, v1: xvii); in his diary Graham noted 'very ungenerous remarks made by chairman about J M Corrie' (Ref MS 36/24/7: 8 October 1935).

10 RCAHMS Minute Book: 14 April 1938.

11 This number includes those in appendices.

12 Dictionary of Scottish Architects (www.scottish architects.org.uk). Accessed 27 October 2016.

13 Graham's diary (Ref MS 36/24/7): 19 September 1935.

14 Graham's diary (Ref MS 36/24/7): 27 November 1935; 19 March, 28 July and 6 November 1936; 4 February 1937.

15 Graham's diary (Ref MS 36/24/7).

16 Graham's diary (Ref MS 36/24/7); Stanley Cursiter (1887-1976) was director of the National Galleries of Scotland at this time; John W M Loney, Edinburgh, was listed as a Life Member of this Society from 1901 until $c 1945$.

17 Graham's diary (Ref MS 36/24/14); this is the Leica camera used by Graham during the war for architectural details and archaeology, and still held at John Sinclair House (see RCAHMS 2015: 32).

18 Graham's diary (Ref MS 36/24/7): 21-4 September 1935; see also Ref MS 229/7 and 229/82.

19 RCAHMS Minute Book: 12 April 1938; NRS DD29/55.

20 This letter has not been located; no additional correspondence on the consideration of Childe has been found - he was not apparently discussed by the Commissioners or Chairman until he issued his complaint, and there is no suggestion that the Secretary of State or Scottish Office took him into consideration.

21 RCAHMS Correspondence file (1938): Graham to Macdonald, 22 July 1938.

22 Ibid.

23 Graham's diary (Ref MS 36/24/14); Corrie's death was recorded in RCAHMS 1946, v1: xvii.

24 RCAHMS Correspondence file (1938): Macdonald to Childe, 26 July 1938.

25 RCAHMS Correspondence file (1938): Childe to Macdonald, 27 July 1938. 
26 Graham's diary (Ref MS 36/24/14).

27 Graham's diary (Ref MS 36/24/14): 24 August 1939.

28 Graham's diary (Ref MS 36/24/14); Gerhard Bersu (1889-1964), a German archaeologist and refugee; Sir John Linton Myres (1869-1954), a British archaeologist; Pedro Bosch Gimpera (1891-1974), a Spanish archaeologist and refugee whose 1936 Rhind lectures on the archaeology of the Iberian Peninsula are unpublished.

29 RCAHMS Progress Report (Ref 102/4): April 1939 to November 1941 (RCAHMS 2015: 2930 ); the Commission's office secretary Helen Maclaren was sent for temporary duty to the Scottish Office on 12 September 1939; Graham's diary (Ref MS 36/24/14); see Note 8; DíazAndreu 2009.

30 RCAHMS Correspondence file (1940): Gatliff to Graham, 30 January 1940.

31 RCAHMS Emergency Survey Correspondence files 1940-2 (Refs 551/1/10/2; 551/1/10/3), a list of vulnerable towns, burghs and parishes extracted from Statutory Rules and Orders 1939 no. 893 (Civil Defence Scotland) seems to have formed the basis of Graham's targets.

32 Air Raid Map, created by Aberdeen City and Aberdeenshire Archives: https://www.google. $\mathrm{com} / \mathrm{maps} / \mathrm{d} / \mathrm{u} / 0 /$ viewer?mid=z8RRvQYE6Eh4 . kO6dzF4En4RM. Accessed 31 May 2016.

33 RCAHMS Emergency Survey Correspondence (Ref 551/1/10/2), letter nos 16-18.

34 Graham's diary (Ref MS 36/24/14).

35 RCAHMS Emergency Survey Correspondence 1940-1 (Ref 551/1/10/2 etc).

36 Graham's diary (Ref MS 36/24/14).

37 RCAHMS Progress (Ref 102/4): April 1939 to November 1941.

38 Examples include Provost Skene's House, Aberdeen, and information on the copies and any payments are held in the project files, as is correspondence with the Royal Incorporation of Architects in Scotland (RCAHMS Emergency Survey Correspondence (Refs 551/1/10/2 to 551/1/10/5)).

39 RCAHMS Correspondence file (1941-4) (Ref 551/1/10/1), letter from Graham to Clapham, 14 October 1943.

40 RCAHMS Emergency Survey Correspondence 1941-2 (Ref 551/1/10/3), letter nos 124 and 12730, 134, 195.

41 RCAHMS Progress (Ref 102/4), April 1939 to November 1941.
42 A microfiche (described in the Progress Report of 1942) survives in the Commission's archive (MS 71); Graham's diary (Ref MS 36/24/8): 5 June 1942; RCAHMS Correspondence 1941-4 (Ref 551/1/10/1): letter nos 150-1.

43 RCAHMS Programme (Ref 102/3 (i)): 4 November 1941.

44 RCAHMS Programme (102/3 (i)): 28 October 1942.

45 RCAHMS Programme (102/3 (i)): 26 October 1943; RCAHMS Progress Report (Ref 102/4), 11 September 1944.

46 Email from Dr E Whinton-Brown, Archive Services, English Heritage, 24 January 2014; RCAHMS 1951: xxviii; RCAHMS Progress (Ref 102/4): 11 September 1944.

47 RCAHMS Progress (Ref 102/4): 1939-45.

48 RCAHMS Minute Book.

49 RCAHMS Correspondence file (1941-4) (Ref 551/1/10/1): 20 January 1942.

50 Graham's diary (Ref MS 36/24/8).

51 RCAHMS Correspondence file (1941-4) (Ref 551/1/10/1): 20 January 1942; see also NRS DD29/55 for the copy received. NRS DD29/55 also contains handwritten notes and a telegram which refer to the Secretary of State as ' $\mathrm{S}$ of $S$ ', and suggest that it was partly from him that doubt over Childe, and the suggestion of other candidates, came.

52 NRS DD29/55: handwritten note for Crosfield discussing Graham's letter; Meikle to Mackay Thomson, 29 January 1942. Further notes in the file refer to the consideration of a Mr Angus at Register House, Annie Dunlop (1897-1973), Elizabeth Haldane (1862-1937), Professor John D Mackie (1887-1978), Agnes Muir Mackenzie (1891-1955) and Dr W Douglas Simpson (1896-1968). Haldane was suggested despite her death some five years earlier. Dickinson, Dunlop, Galbraith and Simpson all became Commissioners in later years (RCAHMS 2015: 158).

53 NRS DD29/55: Meikle to Mackay Thomson, 29 January 1942. Meikle's perception of the Commission may have been accurate in 1938, but perhaps not so in 1941.

54 NRS DD29/55: Stirling Maxwell to Johnston, 30 March 1942; Johnston to Stirling Maxwell, 23 April 1942; Johnston to Childe, 23 April 1942; Childe to Johnston, 23 April 1942. 
55 NRS DD29/55: Stirling Maxwell, 14 April 1942 (detailed handwritten note on Childe's record with Edinburgh and Glasgow police).

56 NRS DD29/55: Stirling Maxwell, 8 April 1942 (detailed handwritten note on Childe's record with MI5).

57 NRS DD29/55: Johnston to Childe, 23 April 1942; Childe to Johnston, 24 April 1942.

58 RCAHMS Commission membership (Ref 101 (i)): Graham to Stirling Maxwell, 30 April 1942; there is every reason to think that at least some further appointments were also problematic: the Secretary of State's suggestion that a member of the Fine Art Commission, socialist John Smith Clarke (1885-1959), should be appointed to RCAHMS in 1943 caused Stirling Maxwell to reply that it would be 'disastrous for the work of the Commission' (NRS DD29/55: Johnston to Stirling Maxwell, 12 January 1943; Stirling Maxwell to Johnston, 26 January 1943).

59 National Archives, Kew, Ref KV2/2148; NRS DD29/55: Stirling Maxwell notes dated 8 and 14 April 1942; see also a 2016 lecture by Dr Katie Meheux of University College London entitled 'Archaeology and espionage: the secret political life of Professor Vere Gordon Childe' http://media.nationalarchives.gov.uk/index.php/ archaeology-espionage-secret-political-lifeprofessor-vere-gordon-childe/. Accessed 23 January 2017.

60 Graham's diary (Ref MS 36/24/8).

61 Graham's diary (Ref MS 36/24/8); RCAHMS Emergency Survey Correspondence file 1942-9 (Ref 551/1/10/5): Stirling Maxwell to Graham, 22 June 1942.

62 RCAHMS Emergency Survey Correspondence File (Ref 551/1/10/5): Graham to Thorne, 29 June 1942, copied to J S Richardson, Inspector of Ancient Monuments (with caveats).

63 Graham's diary (Ref MS 36/24/8): 3 July 1942; see note in Emergency Survey Correspondence file (Ref 551/1/10/5): letter no. 8, see also letter no. 53 with respect to his methods.

64 RCAHMS Emergency Survey Manuscripts (Ref MS 36/273): pp 25a-e; RCAHMS Emergency Survey Correspondence file 1942-9 (Ref 551/1/10/5): letter no. 52; J H Burns later became Professor of the History of Political Thought at University College London (Ralston 2009: 65); Childe's notes on Mull from 1934 are incorporated into the Emergency Survey manuscript material (Ref MS 36/273-5).

65 There is no evidence that Graham ever let Childe drive, perhaps due to his notorious lack of skill in that area (Ralston 2009: 59).

66 Graham's diary (Ref MS 36/24/8).

67 Graham's diary (Ref MS 36/24/8).

68 RCAHMS Emergency Survey Correspondence File 1942-9 (Ref 551/1/10/5): letter no. 24, see also letter nos $31,35,38$.

69 Graham's diary (Ref MS 36/24/8).

70 Graham's diary (Ref MS 36/24/8).

71 Graham's diary (Ref MS 36/24/8).

72 Graham's diary (Ref MS 36/24/8).

73 RCAHMS Emergency Survey Correspondence 1941-2 (Ref 551/1/10/3): letter nos 195, 198.

74 Graham's diary (Ref MS 36/24/8).

75 RCAHMS Emergency Survey Manuscripts (Ref MS 36/273).

76 Graham's diary (Ref MS 36/24/14).

77 The maps used by Graham and Childe are probably those held as part of Graham's archive (Ref 551/476/4/1). One at least (Knapdale and Jura) has an annotated sketch on the rear in Childe's hand, and many mark monuments visited in red and blue, in a pattern that corresponds to the Emergency Survey.

78 RCAHMS Emergency Survey Correspondence 1942-9 (Ref 551/1/10/5): 'Analysis of material published in files', 2 June 1949, appended to a letter from Childe to Graham, 8 June (?) 1949.

79 RCAHMS Programme (Ref 102/3 (i)).

80 RCAHMS Progress Report (Ref 102/4): 28 October 1946.

81 RCAHMS Membership of Commission (to 1963) (Ref 101 (i)): Childe to Stirling Maxwell, 28 October 1946; RCAHMS 1951: xxix.

82 The official recorded number of sites was 636 (RCAHMS 1951: xxviii).

83 Graham's diary (Ref MS 36/24/8).

84 See Note 51.

\section{DOCUMENTARY SOURCES}

HISTORIC ENVIRONMENT SCOTLAND:

RCAHMS COLLECTION, JOHN SINCLAIR HOUSE, EDINBURGH

Angus Graham's diaries:

1 June 1934 to 20 October 1937 (Ref MS 36/24/7);

21 October 1937 to 5 December 1941 (Ref MS 36/24/14); 
6 December 1941 to 11 December 1949 (Ref MS $36 / 24 / 8)$.

RCAHMS Business papers:

Correspondence (1935) (not publicly available);

Correspondence (1938) (not publicly available);

Correspondence (1940) (not publicly available);

Correspondence (1941-4) (Ref Code 551/1/10/1);

Correspondence (Emergency Survey) (Ref Code $551 / 1 / 10 / 2-5)$;

Correspondence (Membership, to 1963) (Ref 101 (i) not publicly available);

Minute Book (held in the library special collection);

Progress reports (to November 1970) (Ref 102/4, not publicly available);

Programmes (to November 1970) (Ref 102/3 (i), not publicly available).

Field notebooks and maps:

Angus Graham (Ref MS 124/2; MS 124/3; MS 124/4);

Vere Gordon Childe (Ref MS 36/190; MS 401/1; MS 401/2);

Ordnance Survey maps annotated by Graham and Childe (Ref 551/476/4/1).

Emergency Survey site descriptions:

Manuscript notes (including sketches), currently held as MS 36/273-5 (Unit ID 23574);

Typescript notes, held in the library (Ref A.1.1.SUR); further copies (with annotations by Angus Graham and Alastair MacLaren) exist in the latter's archive material.

\section{NATIONAL RECORDS OF SCOTLAND}

DD29/55, Scottish Office and Scottish Home Department, correspondence and files discussing appointments to RCAHMS ( $c 1930$ to $c 1960$ ).

THE NATIONAL ARCHIVES, KEW

KV2/2148, Security Service: Personal Files, Vere Gordon Childe, 1917-52.

\section{REFERENCES}

NB RCAHMS County Inventories are referred to simply by the County or area name used in the title.
Anderson, J 1881 Scotland in Early Christian Times: The Rhind Lectures in Archaeology, 1879. Edinburgh: David Douglas.

Anderson, J 1883 Scotland in Pagan Times, The Iron Age: the Rhind Lectures in Archaeology for 1881. Edinburgh: David Douglas.

Anderson, J 1886 Scotland in Pagan Times, The Bronze and Stone Ages: The Rhind Lectures in Archaeology for 1882. Edinburgh: David Douglas.

Anon 1934 'Review: The Royal Commission on the Ancient and Historical Monuments of Scotland, Eleventh report with inventory of monuments and constructions in the Counties of Fife, Kinross and Clackmannan', Antiquity 8: 495-6.

ARC [?AR Cross] 1970 'Obituary, James Smith Richardson', Proc Soc Antiq Scot 102: vii-x.

Armit, I 2003 Towers in The North: The Brochs of Scotland. London: Tempus.

Arthur, K 1948 'Thomas Hastie Bryce 18621946', Obituary Notices of Fellows of The Royal Society 5: 659-65.

Barclay, G 2013 If Hitler Comes. Preparing for Invasion: Scotland 1940. Edinburgh: Birlinn.

Bell, A S (ed.) 1981 The Scottish Antiquarian Tradition: Essays to Mark The Bicentenery of The Society of Antiquaries of Scotland and its Museum. Edinburgh: John Donald.

Bowden, M \& Mackay, D 1999 'Archaeology and the Ordnance Survey revisited: field investigation by the Ordnance Survey Archaeology Division 1947-1983', in Frodsham, Topping \& Cowley (eds), 1-13.

Braidwood, R 1958 'Vere Gordon Childe, 18921957', American Anthropologist 60: 733-6.

Bryce, T H 1940 'The so-called heel-shaped cairns of Shetland, with remarks on the chambered tombs of Orkney and Shetland', Proc Soc Antiq Scot 74: 25-6.

Calder, C S T 1937 'A neolithic double-chambered cairn of the stalled type and later structures on the Calf of Eday, Orkney', Proc Soc Antiq Scot 71: 115-54.

Calder, C S T 1939 'Excavations of Iron Age dwellings on the Calf of Eday in Orkney', Proc Soc Antiq Scot 73: 167-84. 
Calder, C S T 1965 'Cairns, Neolithic Houses and Burnt Mounds in Shetland', Proc Soc Antiq Scot 96: 37-86.

Calder, C S T \& Steer, K A 1951 'Dun Lagaidh and four other prehistoric monuments near Ullapool, Ross and Cromarty', Proc Soc Antiq Scot 83: 68-76.

Caldwell, D H, Ewart, G \& Triscott, J 1998 'Auldhill, Portencross', Archaeological Journal 155: 22-81.

Callander, J G 1929 'Scottish Neolithic Pottery', Proc Soc Antiq Scot 63: 29-98.

Callander, J G 1931 'Notes on (1) Certain Prehistoric Relics from Orkney, and (2) Skara Brae: its Culture and its Period', Proc Soc Antiq Scot 65: 78-114.

Callander, J G \& Grant, W G 1934 'A long stalled chambered cairn or mausoleum (Rousay type) near Midhowe, Rousay, Orkney', Proc Soc Antiq Scot 68: 444-516.

Childe, V G 1930 'Operations at Skara Brae during 1929', Proc Soc Antiq Scot 64: 158-90.

Childe, V G 1931a 'Final report on the operations at Skara Brae', Proc Soc Antiq Scot 65: 27-77.

Childe, V G 1931b Skara Brae, a Pictish Village in Orkney. London: Kegan Paul, Trench, Trubner \& Co.

Childe, V G 1932 'Chambered cairns near Kilfinan, Argyll', Proc Soc Antiq Scot 66: 415-20.

Childe, V G 1935 The Prehistory of Scotland. London: Kegan Paul.

Childe, V G 1938 'Note: A New Skara Brae', The Antiquaries Journal 18: 402-3.

Childe, V G 1942a 'Note: The Chambered Cairns of Rousay', The Antiquaries Journal 22: 13942.

Childe, V G 1942b What Happened in History. Harmondsworth: Allen Lane.

Childe, V G 1943 'A hoard of bronzes from Ballymore, Cowal, Argyll', Proc Soc Antiq Scot 77: 184-7.

Childe, V G 1944a Progress and Archaeology. London: Watts.

Childe, V G 1944b 'An Unrecognised Group of Chambered Cairns', Proc Soc Antiq Scot 78: 26-38.
Childe, V G 1946 Scotland Before the Scots, being the Rhind Lectures for 1944. London: Methuen.

Childe, V G \& Forde, D 1932 'Excavations in two Iron Age forts at Earn's Heugh, near Coldingham', Proc Soc Antiq Scot 66: 152-83.

Childe, V G \& Graham, A 1943 'Some notable prehistoric and medieval monuments recently examined by the Royal Commission on Ancient and Historical Monuments of Scotland', Proc Soc Antiq Scot 77: 31-49.

Childe, V G \& Grant, W G 1939 'A Stone Age settlement at the Braes of Rinyo, Rousay, Orkney. (First Report.)', Proc Soc Antiq Scot 73: 6-31.

Childe, V G \& Grant, W G 1949 'A Stone Age settlement at the Braes of Rinyo, Rousay, Orkney. (Second Report.)', Proc Soc Antiq Scot 81: 16-42.

Childe, V G \& Paterson, J W 1929 'Provisional report on the excavations at Skara Brae, and on finds from the 1927 and 1928 campaigns', Proc Soc Antiq Scot 63: 225-80.

Colvin, H M 1957 'Review: An Inventory of the Ancient and Historical Monuments of Roxburghshire', The English Historical Review 72: 678-80.

Corrie, J M 1932 'Notes on (1) a Two-storeyed Grave at Little Asta, Shetland; (2) Certain Prehistoric Relics from Shetland; and (3) a Viking Brooch of Silver from Skaill Bay, Orkney', Proc Soc Antiq Scot 66: 69-85.

Corrie, J M \& Low, A 1929 'A Short cist at West Puldrite, in the Parish of Evie and Rendall, Orkney. With a Report on the Human Remains found in the Cist', Proc Soc Antiq Scot 63: 190-5.

Cowie, T 1977 'Dalry, Carwinning Hill', Discovery and Excavation in Scotland 1977: 8.

Cowie, T 1978 'Carwinning Hill, hillfort, cairn, structural remains', Discovery and Excavation in Scotland 1978: 28.

Crawford, O G S 1949 Topography of Roman Scotland North of the Antonine Wall. Cambridge: Cambridge University Press.

Curle, A O 1935 'The excavations at Jarlshof, Sumburgh, Shetland', The Antiquaries Journal 15: 26-9. 
Curle, J 1911 A Roman Frontier Post and its People: The Fort of Newstead in The Parish of Melrose. Glasgow: James Maclehose.

Curle, J 1940 'Sir George Macdonald, KCB: 1862-1940. A Memoir', Proc Soc Antiq Scot 74: 123-32.

Díaz-Andreu, M 2009 'Childe and the International Congresses of Archaeology', European Journal of Archaeology 12(1-3): 91-122.

Dunbar, J 1981 'Angus Graham’, Proc Soc Antiq Scot 111: 1-6.

Dunbar, J 1992 'The Royal Commission on the Ancient and Historical Monuments of Scotland: the first eighty years', Transactions of the Ancient Monuments Society 36: 13-77.

Feachem, R W 1959 'Castlehill Wood dun, Stirlingshire', Proc Soc Antiq Scot 90: 24-51.

Forsyth, D J, Bateson, J D \& McDonald, S W 2006 'Thomas Hastie Bryce (1862-1946) - a lesson in the power of observation', Clinical Anatomy 19: 292-8.

Frodsham, P, Topping, P \& Cowley, D (eds) 1999 'We were always chasing time': papers presented to Keith Blood. Newcastle upon Tyne: Northern Archaeology (special edn).

Geddes, G F 2013 'Archaeology at the margins RCAHMS emergency survey in the 1950s', Proc Soc Antiq Scot 143: 363-91.

Gordon, J 1990 'The Objects Themselves: A Short Notice on the Life and Ideas of Angus Graham', Review of Scottish Culture 6: 1-7.

Gordon, J 1993 'Foreword', in Graham, A, Skipness, Memories of a Highland Estate. Edinburgh: Canongate Academic.

Graham, A 1915 'Report on the Partial Excavation of Dun Breac, Skipness', Proc Soc Antiq Scot 49: 50-5.

Graham, A 1919 'A Survey of the Ancient Monuments of Skipness', Proc Soc Antiq Scot 53: 76-118.

Graham, A 1920 'Further Antiquities at Skipness', Proc Soc Antiq Scot 54: 194-204.

Graham, A 1935 The Golden Grindstone. 2006 edn. Guilford, CT: Lyons Press.

Graham, A 1943 'The painted ceiling in the church of St Mary, Grandtully', Proc Soc Antiq Scot 77: $147-54$.

Graham, A 1947a 'Some Observations on the Brochs', Proc Soc Antiq Scot 81: 48-99.
Graham, A 1947b 'Review: Scotland Before the Scots by V Gordon Childe', The Antiquaries Journal 27: 89-90.

Graham, A 1948 'Notes on some Northumbrian "Peles", Proc Soc Antiq Scot 80: 37-43.

Graham, A 1956 'A Memorial of Alexander Ormiston Curle', Proc Soc Antiq Scot 88: 234-6.

Graham, A 1959 'Cairnfields in Scotland', Proc Soc Antiq Scot 90: 7-23.

Graham, A 1981 'In Piam Veterum Memoriam', in Bell (ed.), 212-26.

Graham, A \& Collingwood, R G 1923 'Skipness Castle', Proc Soc Antiq Scot 57: 266-87.

Green, S 1981 Prehistorian - A Biography of $V$. Gordon Childe. Bradford-on-Avon: Moonraker Press.

Harris, D (ed.) 1994 The Archaeology of $V$. Gordon Childe. London: UCL Press.

Hay, G D 1977 'Work of the Royal Commission and the National Monuments Record in the field of industrial archaeology', Scottish Archaeological Forum 8: 1-15.

Henshall, A S 1963 The Chambered Tombs of Scotland, Volume 1. Edinburgh: Edinburgh University Press.

Henshall, A S 1972 The Chambered Tombs of Scotland, Volume 2. Edinburgh: Edinburgh University Press.

Henshall, A S \& Ritchie, J N G 2001 The Chambered Cairns of the Central Highlands. Edinburgh: Edinburgh University Press.

Hingley, R, Moore, H L, Triscott, J E \& Wilson, G 1997 'The excavation of two later Iron Age fortified homesteads at Aldclune, Blair Atholl, Perth and Kinross', Proc Soc Antiq Scot 127: 407-66.

Hutchison, M, Curtis, N \& Kidd, R 2015 'The Knowe of Rowiegar, Rousay, Orkney: description and dating of the human remains and context relative to neighbouring cairns', Proc Soc Antiq Scot 145: 41-90.

Klejn, L 1994 'Childe and Soviet Archaeology: a Romance', in Harris (ed.), 75-93.

Lever, M 2015 'A Person of Interest: Gordon Childe and MI5', Buried History 51: 19-30.

Martlew, R D \& Ruggles, C L N 1996 'Ritual and Landscape on the west coast of Scotland: an 
investigation into the Stone Rows of Northern Mull', Proceedings of the Prehistoric Society 62: 117-31.

Marwick, H 1947 'Review: The Ancient Monuments of Orkney and Shetland', The Scottish Historical Review 26: 79-85.

Moar, P 1948 'A small hoard of polished stone knives and a polished stone adze from the Ward of Shurton, near Lerwick', Proc Soc Antiq Scot 80: 140-1.

Munro, R W 1915 'The Royal Commission on the Ancient and Historical Monuments and Constructions of Scotland', The Scottish Historical Review 12: 238-46.

Nuttgens, P 1959 Reginald Fairlie 1883-1952: A Scottish Architect. Edinburgh: Oliver \& Boyd.

Piggott, C M 1950 'The excavation at Hownam Rings, Roxburghshire', Proc Soc Antiq Scot 82: 193-225.

Piggott, S 1947 'Review: The Royal Commission on the Ancient Monuments of Scotland. Twelfth Report with an Inventory of the Ancient Monuments of Orkney and Shetland', The Antiquaries Journal 27: 92-3.

Piggott, S 1956 'Excavations in passage-graves and ring-cairns of the Clava group, 1952-3', Proc Soc Antiq Scot 88: 173-207.

Proc Soc Antiq Scot 70 1936: 2.

Proc Soc Antiq Scot 72 1938: 233.

Proc Soc Antiq Scot 75 1941: 3.

Radford, C A R 1959 'Review: Royal Commission on the Ancient Monuments of Scotland. The County of Roxburgh. The County of Selkirk', Antiquity 33: 234-5.

Ralston, I 2009 'Gordon Childe and Scottish Archaeology: The Edinburgh Years 1927-46', European Journal of Archaeology 12(1-3): 47-90.

RCAHMS 1909 Berwickshire. Edinburgh: HMSO. RCAHMS 1911a Caithness. Edinburgh: HMSO.

RCAHMS 1911b Sutherland. Edinburgh: HMSO.

RCAHMS 1928 The Outer Hebrides, Skye and the Small Isles. Edinburgh: HMSO.

RCAHMS 1933 Fife, Kinross and Clackmannanshire. Edinburgh: HMSO.

RCAHMS 1946 Orkney and Shetland, 3v. Edinburgh: HMSO.

RCAHMS 1951 Edinburgh. Edinburgh: HMSO.
RCAHMS 1956 Roxburgh, 2v. Edinburgh: HMSO.

RCAHMS 1957 Selkirk. Edinburgh: HMSO.

RCAHMS 1971 Argyll 1: Kintyre. Edinburgh: HMSO.

RCAHMS 1980 Argyll 3: Mull, Tiree, Coll and Northern Argyll. Edinburgh: HMSO.

RCAHMS 1981 The Archaeological Sites and Monuments of South Carrick, Kyle and Carrick District, Strathclyde Region. Edinburgh: RCAHMS.

RCAHMS 1990 North-east Perth, an Archaeological Landscape. Edinburgh: HMSO.

RCAHMS 1994 South-east Perth, an Archaeological Landscape. Edinburgh: HMSO.

RCAHMS 1998 Forts, Farms and Furnaces: Archaeology in the Central Scotland Forest. Edinburgh: RCAHMS.

RCAHMS 2001 'Well sheltered and watered': Menstrie Glen, a Farming Landscape Near Stirling. Edinburgh: RCAHMS.

RCAHMS 2007 In The Shadow of Bennachie: a Field Archaeology of Donside, Aberdeenshire. Edinburgh: RCAHMS \& The Society of Antiquaries of Scotland.

RCAHMS 2015 An Inventory for the Nation. Edinburgh: RCAHMS.

Reynolds, D M 1984 'J M Corrie, archaeologist', Transactions of the Dumfriesshire and Galloway Natural History and Antiquarian Society 59: 94-107.

Reynolds, D M \& Ritchie, J N G 1985 'Walter Gordon Grant: an archaeological appreciation', Proc Soc Antiq Scot 117: 67-73.

Richardson, J S 1948 The Broch of Gurness, Aikerness, West Mainland, Orkney. Edinburgh: HMSO.

Richmond, I A 1943 'Recent discoveries in Roman Britain from the air and field', Journal of Roman Studies 33: 45-54.

Richmond, I A 1944 'Memoir: James Curle', Proc Soc Antiq Scot 78: 145-9.

Ritchie, A 1995 Prehistoric Orkney. London: Batsford and Historic Scotland.

Ritchie, J N G 2002 'James Curle (1862-1944) and Alexander Ormiston Curle (1866-1955): pillars of the establishment', Proc Soc Antiq Scot 132: 19-41. 
Rouse, I 1958 'Vere Gordon Childe: 1892-1957', American Antiquity 24: 82-4.

Sherratt, A 1989 'V. Gordon Childe: Archaeology and Intellectual History', Past and Present 125: 151-85.

Steer, K A 1958 'The early Iron Age homestead at West Plean', Proc Soc Antiq Scot 89: 22751.
Stevenson, R B K 1981 'The Museum, its Beginnings and its Development', in Bell (ed.), 142-212.

Trigger, B 1994 'Childe's relevance to the 1990s', in Harris (ed.), 9-34.

Watson, G P H \& Graham, A 1942 'A mural painting and a carved door at Traquair House, Innerleithen', Proc Soc Antiq Scot 76: 5-7. 
